Mateusz BĄK

mat.bak@student.uj.edu.pl

\title{
PRAWNE, POLITYCZNE, GOSPODARCZE I INFRASTRUKTURALNE PERSPEKTYWY ROZWOJU RYNKU LNG W UNII EUROPEJSKIEJ
}

ABSTRACT Legal, political, economic and infrastructural perspectives of the LNG market development in European Union

The European Union is one of the biggest world gas consumers. At the same time, it is highly dependent on supplies from the Russian Federation. In particular, the countries of the Baltic Region, as well as Finland and Central Eastern Europe states are almost fully dependent on Russian gas. The global decrease in oil prices in recent months has led to similar price reductions on gas market. It also contributed to bigger discount on LNG supplies' price to the European Union. The EU has now a great opportunity to diversify its gas supplies and increase energy security level through wider use of liquefied gas. LNG market creates the opportunity to buy gas on competitive prices and renegotiate on-going long-term contracts. Liquefied gas is widely used not only to produce electricity but also in automotive, petrochemical and medical sector. Full implementation of existing EU legislation, as well as the finalization of an EU strategy on the LNG market will guarantee gas imports at competitive prices to EU countries. However, particular attention should be given to expand gas interconnections and gas storage facilities.

KEYWORDS LNG, liquefied natural gas, energy security, gas supply, European Union 


\section{WSTĘP}

Unia Europejska (UE) jest jednym z największych światowych konsumentów energii. Wśród niezbędnych surowców energetycznych wymienia się węgiel (kamienny i brunatny), ropę naftową, uran i tor. Są one nazywane nośnikami energii pierwotnej, służą bowiem do produkcji energii elektrycznej i cieplnej, jak również są paliwem dla pojazdów spalinowych. O ile dostęp do węgla, uranu czy nawet ropy państwa Unii mają zagwarantowany poprzez wiele dróg dostaw, po konkurencyjnych cenach, o tyle odmiennie przedstawia się sytuacja w odniesieniu do gazu ziemnego. Kierunki importu są, zwłaszcza w przypadku państw Europy Środkowo-Wschodniej, Bałkanów, państw bałtyckich oraz niektórych państw skandynawskich, słabo zdywersyfikowane. Dominującym dostawcą surowca jest Federacja Rosyjska. Tymczasem, według prognoz, zapotrzebowanie na gaz ziemny ma wzrastać. W obliczu wskazywanych problemów rośnie strategiczna wartość LNG (liquified natural gas), czyli gazu skroplonego. Do jego zastosowania niezbędne jest posiadanie przez państwo eksportujące surowiec odpowiedniej infrastruktury skraplającej oraz regazyfikacyjnej przez państwo importujące, jak również odpowiedniej floty metanowców umożliwiających transport tego paliwa.

Celem artykułu jest wykazanie, że w UE, znajdującej się obecnie na wstępnym etapie wdrażania koncepcji tzw. unii energetycznej, istnieją uwarunkowania dla zapewnienia dostępu do LNG po konkurencyjnych cenach, z korzyścią dla unijnej gospodarki i obywateli państw członkowskich. Jednocześnie dla osiągnięcia tych profitów konieczne są określone działania na gruncie prawnym oraz politycznym. Szczególnie istotnym elementem koniecznym do wdrożenia wolnego rynku LNG jest budowa infrastruktury przesyłowej i regazyfikacyjnej. W tym celu niezbędne jest przyznanie priorytetowego charakteru określonym inwestycjom oraz aktywna działalność na forum europejskim.

Niniejszy artykuł powstał w oparciu o metodę analizy instytucjonalno-prawnej. Przeprowadzono analizę raportów podmiotów biznesowych i organizacji międzynarodowych oraz aktów prawnych Unii Europejskiej.

Po zarysowaniu obecnego stanu bezpieczeństwa gazowego UE (część pierwsza) przedstawiono podstawowe informacje dotyczące LNG i procesu zdobywania przez niego obecnego udziału w rynku (część druga). W części trzeciej zaprezentowane zostały uwarunkowania powstania płynnego rynku LNG. Aspekty gospodarcze (część 3.1) zostały poddane analizie pod kątem realiów i prognoz dla kształtowania się czynników mogących wywierać wpływ na wysokość ceny rynkowej LNG. Wiele wskazuje na to, że globalna cena gazu skroplonego będzie spadać. Szersze otwarcie rynku, dzięki nowym drogom importu i przesyłu na terenie Unii, może doprowadzić do ukształtowania się jednolitej ceny dla wszystkich państw członkowskich. Aspekty polityczne (część 3.2) sprowadzają się do wdrożenia skoordynowanej strategii postępowania wobec dostawców LNG przez państwa członkowskie UE. Pomyślność tego procesu zależy od pełnego zrozumienia wartości, jaką dla państw wysoce uzależnionych od jednego dostawcy surowca ma dostęp do nowych dróg importu. W sferze legislacyjnej (część 3.3) wskazane jest zapewnienie pełnego wdrożenia wymogów płynących z aktów trzeciego pa- 
kietu energetycznego, zwłaszcza zasady dostępu stron trzecich do infrastruktury noszącej cechy monopolu naturalnego, przez wszystkie państwa członkowskie, uproszczenie procedur administracyjnych na gruncie systemów prawnych poszczególnych państw unijnych, jak również pełne wdrożenie rozporządzenia w sprawie środków zapewniających bezpieczeństwo dostaw gazu ziemnego (SoS). Najsłabszym ogniwem w łańcuchu właściwie funkcjonującego unijnego rynku dostaw LNG jest sieć infrastrukturalna, której poświęcona jest część 3.4. Rozumie się przez nią nie tylko system terminali regazyfikacyjnych i magazynów LNG, ale przede wszystkim sieć połączeń międzysystemowych pomiędzy państwami członkowskimi oraz podziemnych magazynów gazu. Zauważa się brak odpowiedniej liczby interkonektorów umożliwiających w pełni efektywne wykorzystanie potencjału terminali importowych i magazynów. Co więcej, istniejąca infrastruktura związana z LNG jest rozmieszczona bardzo nierównomiernie. W części piątej ocenione są rozwiązania zaproponowane przez nowa strategię unijną dla LNG i gazu. Skoncentrowano się na prowadzeniu inwestycji infrastrukturalnych i kwestii oparcia planów dla rynku gazu na działalności grup regionalnych. Wdrożenie koniecznych rozwiązań wynikających z opublikowanej w lutym 2016 r. strategii ma zapewnić dostęp do taniego surowca dla państw członkowskich oraz pozytywnie wpłynąć na stabilność cen, zwiększając tym samym poziom bezpieczeństwa energetycznego UE.

\section{POLITYKA GAZOWA UNII EUROPEJSKIEJ}

\subsection{Problemy dywersyfikacyjne UE}

Unia niejednokrotnie już przekonywała się, jak wysoko należy cenić bezpieczeństwo energetyczne. Najpierw państwa członkowskie doświadczyły negatywnych skutków kryzysów naftowych z lat 1973 i 1979, kiedy to w efekcie rynkowej interwencji państw arabskich gwałtownie wzrosły ceny ropy w USA i na całym świecie. Sektor gazowy analogicznych wstrząsów doznał w latach 2006 i 2009, gdy na skutek przerwania dostaw gazu na Ukrainę ucierpiało wiele państw Europy Środkowo-Wschodniej (m.in. Węgry, Słowenia, Polska, Chorwacja) i Zachodniej (Francja, Włochy), oraz w 2010 r., kiedy Federacja Rosyjska, w następstwie konfliktu z Białorusią, ponownie wstrzymała dostawy gazu na Zachód. W 2011 r. Europa była również świadkiem przerwania dostaw gazociągiem Greenstream, łączącym Libię i Włochy ${ }^{1}$. Do zaburzeń w dostawach surowców energetycznych dochodziło więc na przestrzeni ostatnich lat stosunkowo często. UE importuje aż 53\% zużywanej energii, a w przypadku samego tylko gazu odsetek ten jest jeszcze wyższy i wynosi 66\%. Aż sześć państw Unii zależy od jednego dostawcy gazu, którym jest Rosja². Jednocześnie zauważyć można wzrastający rokrocz-

M. Ruszel, Znaczenie terminali LNG na wspólnym rynku gazu ziemnego, „Polityka i Społeczeństwo” 2014, nr 4, s. 55.

2 Komunikat Komisji do Parlamentu Europejskiego i Rady: Europejska strategia bezpieczeństwa energetycznego, Komisja Europejska, Bruksela, 28 V 2014, s. 2, [online] http://eur-lex.europa.eu/legal-content/PL/TXT/PDF/?uri=CELEX:52014DC0330\&from=PL, 25 III 2016. 
nie odsetek rosyjskiego gazu na tle całkowitego importu surowca do UE. W $2012 \mathrm{r}$. osiągnął on poziom $39 \%^{3}$, w trzecim kwartale 2015 r. było to $41 \%^{4}$, wobec $42 \%$ z końcem roku poprzedniego ${ }^{5}$. Na tym polega dywersyfikacyjny problem UE. O ile rynek dostaw węgla kamiennego oraz uranu, które służą generacji energii elektrycznej, jak również rynek ropy naftowej można sklasyfikować jako zdywersyfikowany (paliwa są dostępne po niskich cenach, od wiarygodnych dostawców, zapewnione są liczne kanaty ich transportu), o tyle sytuacja na rynku gazu ziemnego przedstawia się odmiennie. Okazuje się, że państwa „starej” Unii uzależnione są od dostaw ze Wschodu w mniejszym stopniu niż państwa Europy Środkowo-Wschodniej, w których współczynnik ten sięga 65-100\%. W dalszym ciągu kontynent dzieli więc na dwoje swoista "gazowa kurtyna"6.

Gaz ziemny bez wątpienia zaliczyć można do strategicznych surowców. Jest on odpowiedzialny nie tylko za produkcję ciepła w gospodarstwach domowych. Znaczne ilości przeznaczane są na potrzeby przemysłu chemicznego ${ }^{7}$, coraz większa część służy również produkcji energii elektrycznej w tzw. blokach gazowo-parowych ${ }^{8}$. Należy zauważyć, że udział surowca w ogólnym bilansie zużycia energii w UE jeszcze w $2010 \mathrm{r}$. wynosił $25,1 \%$, podczas gdy w 2012 r. spadł do poziomu $23,4 \%{ }^{9}$, zaś w 2014 r. $21,6 \%{ }^{10}$. Wiąże się to z malejącą rolą gazu ziemnego w bilansie energetycznym na

Main origin of primary energy imports, EU-28, 2003-13 (\% of extra EU-28 imports), Eurostat, [online] http://ec.europa.eu/eurostat/statistics-explained/images/0/07/Main_origin_of_primary_energy_ imports\%2C_EU-28\%2C_2003\%E2\%80\%9313_\%28\%25_of_extra_EU-28_imports\%29_YB15. png, 24 IV 2016.

4 Quarterly Report on European gas markets. Market observatory for energy, European Commission, DG Energy, vol. 8, issue 3, third quarter of 2015, s. 3, [online] https://ec.europa.eu/energy/sites/ener/ files/documents/quarterly_report_on_european_gas_markets_q3_2015.pdf, 25 IV 2016.

5 Quarterly Report on European gas markets. Market observatory for energy, European Commission, DG Energy, vol. 7, issue 4, fourth quarter of 2014, s. 8, [online] https://ec.europa.eu/energy/sites/ener/ files/documents/quarterly_report_on_european_gas_markets_2014_q4.pdf, 25 IV 2016.

6 M. Kiedrowska-Pryka, Zależności Unii Europejskiej od zewnętrznych dostaw surowców energetycznych struktura zużycia nośników energii i ich dywersyfikacja w krajach cztonkowskich UE, [w:] Bezpieczeństwo energetyczne. Rynki surowców i energii. Teraźniejszość i przysztość, t. 1: Polityka, gospodarka, zasoby naturalne i logistyka, red. P. Kwiatkiewicz, Poznań 2014, s. 421.

7 Dla przykładu, w Polsce największym odbiorcą gazu jest chemiczna spółka Azoty, zaś na Litwie - AB Achema.

8 W Polsce istnieje wiele takich instalacji. Dla przykładu wskazać można elektrociepłownie w Rzeszowie, Zielonej Górze, Nowej Sarzynie. W budowie zaś znajdują się m.in. instalacje w: Płocku - 463 MWe (budowana przez PKN Orlen, z planowaną datą oddania do użytku w drugim kwartale 2016 r.) i 596 MWt, Stalowej Woli - 450 MWe i 240 MWt (Tauron i PGNiG). Źródło: Centrum Informacji o Rynku Energii, [online] http://www.rynek-energii-elektrycznej.cire.pl, 25 III 2016.

9 EU Energy markets in 2014, Luxembourg: Publications Office of the European Union, 2014, s. 6, [online] http://ec.europa.eu/energy/sites/ener/files/documents/2014_energy_market_en.pdf, 24 IV 2016.

10 Obliczenia własne na podstawie: BP statistical review of world energy, VI 2015, s. 41, [online] https:// www.bp.com/content/dam/bp/pdf/energy-economics/statistical-review-2015/bp-statistical-review-of-world-energy-2015-full-report.pdf, 24 IV 2016. 
przestrzeni kilku ostatnich lat, po tzw. kryzysie ekonomicznym. Aktualna koniunktura na rynku wskazuje jednak na rychłe odwrócenie się przedstawionego trendu.

Rynek gazu jest rynkiem globalnym. Silnie zaznaczają się na nim jednak wpływy rynków regionalnych ${ }^{11}$. Jeszcze kilkanaście lat temu przyjmował on de facto postać wielu rynków lokalnych, w odróżnieniu od jednolitego globalnego rynku ropy naftowej $^{12}$. Największym dostawcą do UE pozostaje Federacja Rosyjska. Nie jest tajemnicą, że gospodarka surowcowa stanowi instrument prowadzenia polityki międzynarodowej Rosji oraz narzędzie utrzymania strefy wpływów na terenie państw Europy Środkowo-Wschodniej. Teoria tej tzw. doktryny Falina-Kwiecińskiego znajduje odzwierciedlenie w oficjalnych dokumentach statuujących politykę energetyczną państwa ${ }^{13}$. Widocznymi przykładami jej zastosowania są nie tylko wyreżyserowane przerwy w dostawach gazu w ciągu ostatnich kilkunastu lat, ale również łatwość, z jaką Rosjanom udaje się przekonać wiele państw europejskich do udziału w projektowanych przez siebie inwestycjach mających na celu konsumowanie własnego surowca.

W sektorze gazowym wyraźnie zarysowuje się problem Unii Europejskiej, jakim jest brak zdolności do wypracowania jednolitego stanowiska w przedmiocie dostaw. W Europie wciąż preferowana jest dwustronna współpraca z Rosją zamiast stworzenia wspólnego frontu reprezentującego interesy Unii ${ }^{14}$. Szczególnie wyraźnie problem ten uwidacznia się podczas trwających uzgodnień dotyczących budowy trzeciej oraz czwartej nitki gazociągu Nord Stream (tzw. Nord Stream II).

Trzeba jednak wskazać, że zależność na linii UE - Federacja Rosyjska nie jest jednostronna. Aż 71\% eksportu gazu z Rosji w 2013 r. trafiło do państw Unii ${ }^{15}$. W 2014 r. spośród ponad $187 \mathrm{mld} \mathrm{m}^{3}$ gazu wyeksportowanego samą tylko drogą rurociągową aż niemalże $148 \mathrm{mld} \mathrm{m}^{3}$ (79\%) trafiło na rynek europejski (obejmujący nie tylko państwa $\mathrm{UE})^{16}$, przy czym warto zauważyć, że według najnowszych danych w 2015 r. całkowity import do Europy wzrósł do ok. $160 \mathrm{mld} \mathrm{m}^{3}$ i prawdopodobnie utrzyma się na tym poziomie również w 2016 r., po zwiększeniu rosyjskich dostaw do Francji, Włoch, Wielkiej Brytanii czy Austrii ${ }^{17}$.

11 R. Zajdler, Polski rynek hurtowy gazu ziemnego na tle rynków Unii Europejskiej, Warszawa 2014, s. 6, [online] http://www.zajdler.eu/raporty/show_pdf.php?ID=8, 26 III 2016.

12 J. Baily, R. Lidgate, $L N G$ price reviews: a sign of the times, „Journal of World Energy Law and Business” 2014, vol. 7, no. 2, s. 140, [online] DOI: 10.1093/jwelb/jwt017.

13 Np. w Strategii bezpieczeństwa Federacji Rosyjskiej z 2003 r.

14 Tamże, s. 424.

15 Impact of US LNG exports on Europe - White Paper, Energy Mining Advisory Partnership, s. 1, [online] http://energyminingadvisorypartnership.github.io/impact_of_us_lng_on_exports_on_europe.pdf, 25 III 2016.

16 BP Statistical Review..., s. 28.

17 Zubkov: Gazprom in 2016 could supply Europe with 160 billion cubic meters of gas, FreeNews, 20 I 2016, [online] http://freenews.xyz/2016/01/20/zubkov-gazprom-in-2016-could-supply-europe-with-160-billion-cubic-meters-of-gas-2/, 25 III 2016. 


\subsection{Wykorzystanie gazu w UE}

Na przestrzeni lat 2004-2014 światowy wzrost wydobycia gazu wyniósł ok. 27,5\%. Niemalże w równie szybkim tempie wzrastał globalny popyt na surowiec ${ }^{18}$. Jednocześnie konsumpcja w Unii Europejskiej podlegała odmiennym trendom, regularnie spadając od kilku lat. O ile w $2010 \mathrm{r}$. zapotrzebowanie wynosiło $502 \mathrm{mld} \mathrm{m}^{3}$, o tyle dwa lata później było to już $445 \mathrm{mld} \mathrm{m}^{3}$, zaś w 2014 r. $-387 \mathrm{mld} \mathrm{m}^{3}{ }^{19}$. Wynika to z kilku czynników. Po pierwsze, jest efektem spowolnienia europejskiej gospodarki na skutek kryzysu ekonomicznego, którego negatywne skutki wciąż dają o sobie znać. Po drugie, jest skutkiem zjawisk atmosferycznych - łagodniejszych zim w ostatnich latach. Po trzecie, wpływ na to wywarł również wzrost znaczenia OZE w gospodarce. Równolegle do powyższych zjawisk obserwowano spadek importu LNG utrzymujący się mniej więcej od $2011 \mathrm{r}$. W przypadku UE wyniósł on w latach 2012 i 2013 odpowiednio $27 \%$ i $28,5 \%{ }^{20}$.

Mogłoby się wydawać więc, że czynniki te, wpływające na mniejsze zapotrzebowanie na gaz, wpłyną na zmniejszenie uzależnienia od dostaw z Federacji Rosyjskiej. Skutek taki udałoby się uzyskać, gdyby nie fakt, iż rodzime wydobycie gazu na terenie UE nie jest wysokie, a w dodatku regularnie spada. Od 2010 r. w ciągu czterech lat uległo zmniejszeniu o 25\% i w $2014 \mathrm{r}$. wyniosło finalnie niespełna $132 \mathrm{mld} \mathrm{m}^{321}$. Głównym powodem tego stanu rzeczy jest wyczerpywanie się złóż na Morzu Północnym oraz znaczna redukcja produkcji w holenderskim Groningen, spowodowana serią wstrząsów sejsmicznych w ostatnich latach ${ }^{22}$. Produkcja gazu w Holandii w 2015 r. prawdopodobnie okaże się niemalże trzykrotnie niższa niż w 2013 r. ${ }^{23}$ Międzynarodowa Agencja Energii (International Energy Agency - IEA) prognozuje utrzymanie produkcji na niskim poziomie na terenie UE do końca dekady ${ }^{24}$.

Brakującą ilość surowca, tj. w 2014 r. ok. 255 mld m³ , wspólnota zmuszona była sprowadzić z zagranicy. W rzeczywistości, na skutek pewnego, choć wszakże niewielkiego eksportu gazu z państw UE konieczne jest sprowadzenie większej ilości w ramach dostaw. Dla przykładu, w 2013 r. import finalnie wyniósł aż $305 \mathrm{mld} \mathrm{m}^{3}$ (z czego 39\% z kierunku rosyjskiego), co przełożyło się na zaspokojenie w 66\% zapotrzebowania na gaz ziemny ${ }^{25}$.

\footnotetext{
18 BP statistical review..., s. 22-23.

19 Tamże, s. 23.

20 T. Tański, Funkcje Terminalu LNG w Świnoujściu, [w:] Prawne uwarunkowania konkurencji na rynku gazu, red. B. Popowska, E. Kosiński, P. Lissoń, Warszawa 2015, s. 219.

$21 \quad$ BP Statistical Review..., s. 24.

22 Key natural gas trends 2015, International Energy Agency, s. 3, [online] https://www.iea.org/publications/freepublications/publication/KeyNaturalGasTrends.pdf, 25 III 2016.

23 Tamże.

24 Gas - medium-term market report 2015. Market analysis and forecast to 2020, International Energy Agency, 2015, s. 6, [online] https://www.iea.org/Textbase/npsum/MTGMR2015SUM.pdf, 25 III 2016.

25 Komunikat Komisji do Parlamentu Europejskiego i Rady: Europejska strategia..., s. 2.
} 
Można by sądzić, że straty wynikające z malejącej produkcji gazu na terenie UE, nawet wobec konieczności importu z Rosji, rekompensowane będą choć częściowo przez spadającą konsumpcję, jaką można było zaobserwować na przestrzeni ostatnich lat, co wynika z przedstawionych powyżej zestawień. Analitycy oceniają jednak, że już 2015 r. przyniósł wzrost zapotrzebowania na poziomie $7 \% \mathrm{w}$ porównaniu z rokiem poprzednim $^{26}$. Oznacza to, że przerwany został w UE trwający od 2010 r. regres. Wtedy to po raz ostatni zanotowano wzrost konsumpcji gazu na terenie wspólnoty ${ }^{27}$. Równolegle zaobserwowano obecnie wzrost importu gazu do UE. Podobnie ma być w kolejnych latach. Wzrost konsumpcji w Unii spowodowany jest warunkami klimatycznymi (surowszą zimą), wzrostem aktywności przemysłowej, a także spadkiem wykorzystania energii wodnej w państwach takich jak Niemcy, Hiszpania czy Włochy ${ }^{28}$.

Równolegle do opisywanych zjawisk na terenie Unii wprowadzane są poszczególne wymogi tzw. polityki klimatyczno-energetycznej, wymagającej w perspektywie do 2030 r.: redukcji emisji $\mathrm{CO}_{2}$ o 40\% (względem 1990 r.), wzrostu efektywności energetycznej o $27 \%$ oraz zapewnienia udziału energii ze źródeł odnawialnych w bilansie energetycznym UE na poziomie $27 \%$. Abstrahując od racjonalności oraz ekonomicznej opłacalności przyjętej przez Europę polityki w tym zakresie, zauważyć należy, że instalacje produkujące tzw. energię odnawialną (wiatraki, ogniwa fotowoltaiczne) stanowią bardzo niestabilne źródła energii. Poziom ich generacji zależny jest od panujących warunków pogodowych, zaś nadmiar energii nie może być, przy obecnym stanie rozwoju technologicznego, efektywnie magazynowany. Wobec tego rekomenduje się łączenie generacji z elektrowni napędzanych odnawialnymi źródłami energii (OZE) z generacją $\mathrm{z}$ tych, które działają w oparciu o gaz. Elektrownie gazowe, w przeciwieństwie do bloków węglowych, są bardziej elastyczne operacyjnie: mogą być w krótszym czasie uruchamiane i wyłączane, jak również emitują o połowę mniej gazów cieplarnianych niż generacja węglowa. Można się więc spodziewać, że i ten czynnik sprawi, że w naturalny sposób będzie rosło wykorzystanie gazu w UE. Nie bez wpływu na poziom konsumpcji pozostanie również stopniowy wzrost całkowitego zużycia energii na terenie Unii, które do 2020 r. może wzrosnąć nawet o 5-9\% ${ }^{29}$.

Wobec powyższych okoliczności prognozuje się wzrost importu gazu z Rosji, jak również wzrost importu $\mathrm{LNG}^{30}$ (ryc. 1). Zdaniem ośrodka analitycznego Wood Mackenzie dostawy samego tylko gazu skroplonego już wzrosły w Europie w samym 2015 r. o 14\% i osiągnęły wartość $37 \mathrm{mln}$ ton (ok. $\left.45 \mathrm{mld} \mathrm{m}^{3}\right)^{31}$, co daje ok. 13,5\% udziału w rynku

26 Unia Europejska - LNG może skorzystać na wzrostowym trendzie konsumpcji gazu, LNG Snapshot, 22 XI 2015, [online] http://lngsnapshot.com/?p=326, 25 III 2016.

27 Tamże.

28 Current trends \& prospects of natural gas, CEDIGAZ, the International Association for Natural Gas, XII 2015, s. 5, [online] http://www.cedigaz.org/documents/2015/PresAB2015.pdf, 25 III 2016.

29 M. Kiedrowska-Pryka, Zależności Unii Europejskiej..., s. 420.

30 Current trends \& prospects..., s. 6.

31 A. Shiryaevskaya, More than half of U.S. LNG is destined for Europe, WoodMac says, Bloomberg Business, 15 I 2016, [online] http://www.bloomberg.com/news/articles/2016-01-15/more-than-half-of-u-s-lng-is-destined-for-europe-woodmac-says, 25 III 2016. 
światowym ${ }^{32}$. Według najnowszych danych na skutek wzmożonego obrotu gazem skroplonym na Starym Kontynencie w 2015 r. udział ten mógł wzrosnąć nawet do 15\% ${ }^{33}$.

\section{Ryc. 1. Zmiany wolumenu konsumpcji gazu ziemnego w Unii Europejskiej w porównaniu z poprzedzającym rokiem}

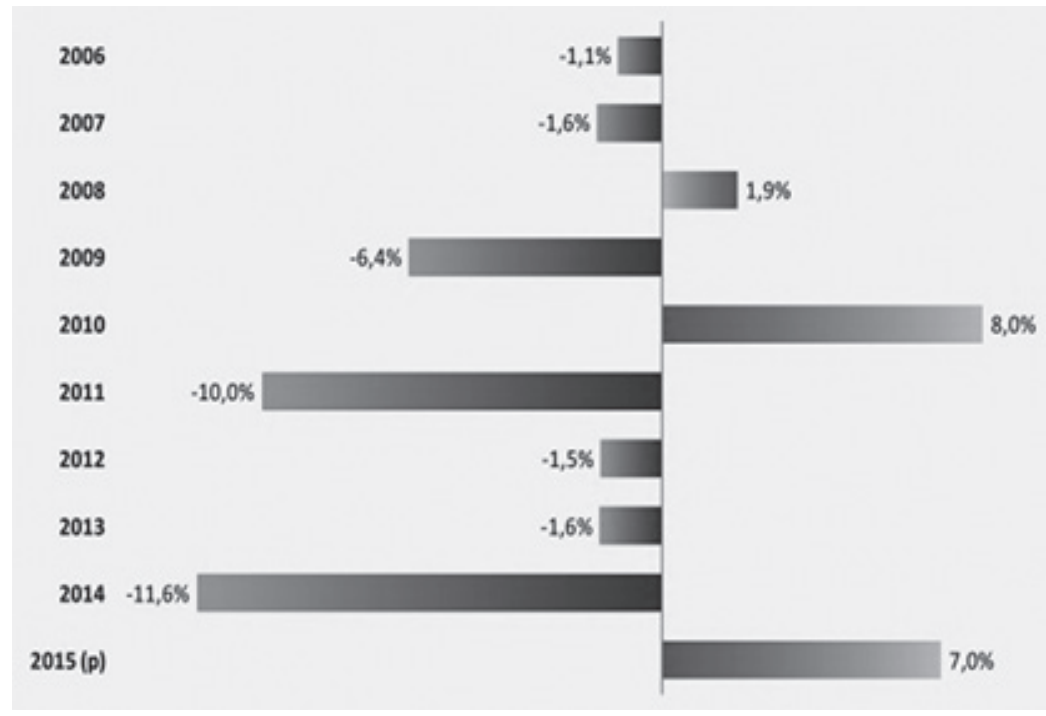

Źródło: Unia Europejska - LNG może skorzystać na wzrostowym trendzie konsumpcji gazu, LNG Snapshot, 22 XI 2015, [online] http://lngsnapshot.com/?p=326, 25 III 2016.

\subsection{Infrastruktura gazowa UE}

Obecny poziom bezpieczeństwa gazowego UE jest daleki od satysfakcjonującego nie tylko z racji wysokiego poziomu uzależnienia od dostaw z jednego kierunku. Problemem jest również wciąż niewystarczająca liczba połączeń międzysystemowych pomiędzy poszczególnymi państwami członkowskimi. Istniejąca na terenie UE infrastruktura nie zapewnia pełnej elastyczności przepływów surowca ${ }^{34}$. Poczyniono już pierwsze kroki w kierunku utworzenia połączonego rynku. Przede wszystkim przyjęto instrumentarium prawne wynikające $\mathrm{z}$ tzw. trzeciego pakietu energetycznego (tj. Rozporzadzenia Parlamentu Europejskiego i Rady (WE) nr 715/2009 z 13 lipca 2009 r. w sprawie warunków dostępu do sieci przesytowej gazu ziemnego oraz Dyrektywy Parlamentu Europejskiego i Rady 2009/73/WE z 13 lipca 2009 r. dotyczacej wspólnych zasad rynku wewnętrznego gazu ziemnego). Jednocześnie, wcielając w życie postano-

32 Terminale importowe LNG sq inwestycjami strategicznymi, LNG Snapshot, 23 IX 2015, [online] http://lngsnapshot.com/?p=181, 25 III 2016.

33 Rekord importu LNG pobity... Dzięei Europie, LNG Snapshot, 13 IV 2016, [online] http://lngsnapshot.com/?p=448, 19 V 2016.

34 M. Ruszel, Znaczenie terminali $L N G$..., s. 50. 
wienia kodeksów sieci ${ }^{35}$ dotyczących alokacji zdolności przesyłowych gazu ziemnego, utworzono w 2013 r. platformę PRISMA, w ramach której dochodzi do alokowania zdolności na przepustowościach międzysystemowych pomiędzy poszczególnymi państwami ${ }^{36}$. Tworzenie tego typu pożądanych, rzecz jasna, mechanizmów nie wywrze jednak właściwego skutku bez budowy odpowiedniej infrastruktury, która będzie realizować przesył gazu. Ten element jest jak na razie zaniedbywany.

Problem brakujących połączeń infrastrukturalnych ma szczególne znaczenie dla kształtującej się w UE strategii wykorzystania LNG. Okazuje się, że państwa Półwyspu Iberyjskiego oraz Apenińskiego, które z racji położenia geograficznego mają największy potencjał do odbioru gazu skroplonego, jak również dysponują obecnie największą liczbą instalacji regazyfikacyjnych w Europie, są najgorzej zintegrowane z sieciami gazowymi innych państw. Pomiędzy Francją a Włochami nie istnieje żadne połączenie, zaś między Francją a Hiszpanią - jedno, o stosunkowo niskiej przepustowości (ok. 1,5 $\left.\mathrm{mld}^{3}\right)^{37}$. Wciąż brakuje również elementów tzw. Korytarza Północ-Południe, który ma łączyć Polskę, Czechy, Słowację, Węgry oraz Chorwację, umożliwiając wymianę gazu skroplonego z jednej strony odbieranego przez terminal w Świnoujściu, a z drugiej - przez wciąż pozostający w sferze planów terminal na wyspie Krk w Chorwacji.

\section{LNG}

\subsection{Historia}

Korzeni technologii skraplania gazu ziemnego szukać należy jeszcze w XIX w. Wtedy to brytyjski chemik Michael Faraday, prowadząc prace badawcze w zakresie skraplania poszczególnych rodzajów gazów, dokonał po raz pierwszy przemiany z formy gazowej w ciekłą ${ }^{38}$. W $1941 \mathrm{r}$. w Cleveland w stanie Ohio powstała pierwsza instalacja skraplająca o przeznaczeniu komercyjnym ${ }^{39}$. W 1959 r. zainicjowano transport skroplonego gazu z USA do Wielkiej Brytanii. Brytyjczycy przez pewien czas zainteresowani byli jednak przede wszystkim tanimi dostawami LNG z Wenezueli. Pomimo to, wskutek uruchomienia terminali na północnym wybrzeżu Afryki, rozpoczęto import z Algierii. Dostawy LNG do Europy wyhamowały dopiero po odkryciu złóż gazu na Morzu Północnym. Lata 70. i 80. XX w. to początek zainteresowania LNG rynków azjatyckich. W tym czasie Japonia oraz Korea Południowa zapoczątkowały prace nad elek-

35 Kodeksy sieci to dokumenty wydawane na podstawie rozporządzeń trzeciego pakietu energetycznego, zawierające warunki pracy sieci przesyłowych. Przygotowywane są odrębnie dla systemu elektroenergetycznego oraz dla systemu gazowego.

36 M. Ruszel, Znaczenie terminali $L N G$..., s. 51.

37 Tamże, s. 53.

38 K. Liuhto, A liquefied natural gas terminal boom in the Baltic Sea region?, „Electronic Publications of Pan-European Institute" 2012, nr 5, s. 9, [online] https://www.utu.fi/fi/yksikot/tse/yksikot/PEI/ raportit-ja-tietopaketit/Documents/Liuhto\%20LNG.pdf, 25 III 2016. 
trowniami gazowymi, czego efektem było nadanie nowej dynamiki rynkowi gazu skroplonego $^{40}$. W 1969 r. Japończycy rozpoczęli import surowca z Alaski, zaś już cztery lata później uznali LNG za surowiec o charakterze strategicznym, umożliwiającym uniezależnienie się od importu ropy z niestabilnego terenu Bliskiego Wschodu ${ }^{41}$. Pomimo to w 1980 r. sprzedawano na świecie wciąż mniej niż 20 mln ton LNG ${ }^{42}$.

\subsection{Właściwości fizykochemiczne}

LNG to gaz ziemny doprowadzony do postaci skroplonej w temperaturze $-162^{\circ} \mathrm{C}$. Jego transport odbywa się za pomocą specjalnie do tego przystosowanych statków, tzw. metanowców. W skład LNG wchodzi przede wszystkim metan (ok. 85-90\%), a w mniejszych ilościach również: etan, azot, propan i butan. Gaz po skropleniu osiąga objętość ok. 600 razy mniejszą ${ }^{43}$. Dzięki temu metanowiec Al-Nuaman, który 11 grudnia 2015 r. dostarczył do gazoportu w Świnoujściu 210 tys. m³ gazu w postaci skroplonej, zapewnił w ten sposób pokrycie trzydniowego zapotrzebowania na gaz dla całej Polski. Transportowana ilość po regazyfikacji przełożyła się bowiem na aż $120 \mathrm{mln} \mathrm{m}^{3}$ gazu przeznaczonego dla sieci gazowniczej ${ }^{44}$.

\subsection{Zastosowanie LNG}

Gaz skroplony stanowi szansę nie tylko na zaspokojenie potrzeb w zakresie produkcji energii elektrycznej, zaopatrzenia odbiorców przemysłowych w sektorze chemicznym oraz zapewnienie źródła ciepła gospodarstwom domowym i przemysłowym. LNG znajduje też zastosowanie w przemyśle motoryzacyjnym jako paliwo. W styczniu 2015 r. w Warszawie oddano do użytku pierwszą w Europie stacjonarną instalację paliw LNG. Jednocześnie polski Solbus dostarczył 35 autobusów przegubowych napędzanych gazem skroplonym, zaś Gazprom Germania przygotował niezbędną infrastrukturę (stacje tankowania) oraz rozpoczął dostarczanie paliwa ${ }^{45}$. W przeciągu ostatnich kilku miesięcy otwarto również stację LNG/CNG w Śremie ${ }^{46}$. Po ulicach

40 Historia, Polskie LNG, [online] http://www.polskielng.pl/lng/historia-lng/, 25 III 2016.

41 D. Yergin, M. Stoppard, The Next Prize, „Foreign Affairs” 2003, vol. 82, no. 6, s. 107, [online] https:// www.foreignaffairs.com/articles/2003-11-01/next-prize, 19 V 2016.

42 K. Liuhto, A liquefied natural gas terminal boom..., s. 9.

43 A. Sikora, P. Lenartowicz, Sen o gazie. LNG a polska energetyka, „Energetyka Cieplna i Zawodowa” 2015, nr 7, s. 2, [online] http://www.ise.com.pl/wp-content/uploads/2015/11/Sen-o-gazie_ECiZ-7_2015.pdf, 25 III 2016.

44 T. Furman, Al Nuaman zacumowat w Świnoujściu, „Parkiet” 2015, 11 XII, [online] http://www.parkiet.com/artykul/1452950.html, 25 III 2016.

45 A. Kublik, Gazprom Germania zarobi w Warszawie na gazowych autobusach, Wyborcza.biz, 7 XI 2013, [online] http://wyborcza.biz/biznes/1,147744,14914096,Gazprom_Germania_zarobi_w_ Warszawie_na_gazowych_autobusach.html, 22 IV 2016.

46 First Poland LNG station opened, LNG World News, 5 I 2016, [online] http://www.lngworldnews. com/first-polish-lng-station-opened/, 25 III 2016. 
Wałbrzycha, Warszawy i Olsztyna poruszają się już autobusy komunikacji miejskiej napędzane paliwem $\mathrm{LNG}^{47}$.

LNG może służyć jako paliwo zarówno dla pojazdów samochodowych, jak i lokomotyw, helikopterów, samolotów ponaddźwiękowych. Znajduje zastosowanie także w przemyśle rafineryjno-petrochemicznym, gdzie użytkowany jest jako chłodziwo, oraz w medycynie, zwłaszcza w transplantologii (do konserwowania krwi i pobranych narządów). Niewykluczone, że większy obrót gazem skroplonym doprowadzi do budowy stacji do bunkrowania statków ${ }^{48}$. Prekursorski pod kątem zastosowania gazu skroplonego jako napędu do okrętów morskich okazał się norweski projekt Glutra zrealizowany w 2001 r. $^{49}$

LNG jest paliwem zawierającym stosunkowo niewielkie ilości siarki, co może uczynić go cennym źródłem energii $\mathrm{w}$ dobie zaostrzania norm emisji zanieczyszczeń ${ }^{50}$. W tym kontekście warto wskazać, że od 1 stycznia 2015 r. mocą dyrektywy 2012/33/ WE na terenie niektórych akwenów europejskich ${ }^{51}$ zaostrzono dziesięciokrotnie przepisy dotyczące zawartości siarki w paliwach żeglugowych ${ }^{52}$.

Dla zastosowania LNG jako paliwa żeglugowego niezbędne jest przygotowanie stosownej infrastruktury, tj. terminali małej i średniej wielkości, które będą mogły pełnić funkcje lokalnych centrów dystrybucyjnych, prowadzić załadunek statków bunkrowych, przeładowywać LNG na cysterny, jak również dostarczać gaz po regazyfikacji do obiektów przemysłowych i gospodarstw domowych ${ }^{53}$. Strategia Komisji Europejskiej zatytułowana "Czysta energia dla transportu” zakłada, że do 2025 r. we wszystkich portach morskich oraz śródlądowych Transeuropejskiej Transportowej Sieci Bazowej (TEN-T) będą istniały ogólnodostępne punkty udostępniania $\mathrm{LNG}^{54}$.

\subsection{Rozwój rynku LNG}

Próbując sprecyzować czynniki determinujące powstanie europejskiego rynku LNG, nie sposób nie odnieść się do globalnych trendów na rynku gazu, w tym gazu skroplonego. Europa nie stanowi wszakże samotnej wyspy na mapie świata. Dostawy LNG stworzyły nowe perspektywy dla państw, które do tej pory uzależnione były od importu drogą rurociągową. Wolumen gazu ziemnego przesyłanego tradycyjnym kanałem wzrósł w latach 2002-2012 o 64\%. Tymczasem ilość surowca transportowanego drogą morską przez metanowce - aż o ponad $200 \%$. Rynek dostaw LNG wzrastał więc we

T. Tański, Funkcje Terminalu LNG..., s. 228.

48 W. Kaźmierczak, Bezpieczeństwo energetyczne. Implikacje uzależnienia Polski od importu gazu ziemnego (zarys problemu), Warszawa 2008, s. 90-92.

49 A. Grobarčíková, J. Sosedová, T. Kalina, Development of LNG Infrastructure in Europe, „Naše more” 2016, vol. 63, no. 1, s. 32, [online] DOI: 10.17818/NM/2016/1.5.

$50 \quad$ M. Ruszel, Znaczenie terminali $L N G$..., s. 54.

51 M.in. Morze Bałtyckie, kanał La Manche, Morze Północne.

52 T. Tański, Funkcje Terminalu LNG..., s. 225.

53 Tamże, s. 226.

54 Tamże, s. 228. 
wskazanym czasie w wymiarze ok. $8 \%$ rocznie. Czynnikiem pogłębiającym powszechność LNG stała się postępująca globalizacja rynku gazu ${ }^{55}$.

W chwili obecnej najwięcej LNG eksportują: Katar (77,8 $\mathrm{mln}$ ton rocznie), Australia (29,4 mln ton), Malezja (25 mln ton), Nigeria (20,4 mln ton), Indonezja (16,1 mln ton), Trynidad i Tobago (12,5 mln ton), Algieria (12,1 mln ton), Rosja $\left(10,9 \mathrm{mln}\right.$ ton), Oman $\left(7,8 \mathrm{mln}\right.$ ton), Papua-Nowa Gwinea $(7 \mathrm{mln} \text { ton })^{56}$. Do największych importerów należą z kolei: Japonia (195 mln ton zdolności importowych rocznie, 34\% światowego importu LNG), Korea Południowa, Chińska Republika Ludowa, Indie, Tajwan, Wielka Brytania, Hiszpania ${ }^{57}$. Spośród państw UE w 2015 r. najwięcej gazu skroplonego sprowadzity: Wielka Brytania $\left(9,8 \mathrm{mln}^{\text {ton }}{ }^{58}\right)$, Hiszpania $(8,9 \mathrm{mln}$ ton), Francja (4,4 mln ton) oraz Włochy (4,2 mln ton $)^{59}$. Terminale posiadaja jednak również Belgia, Grecja, Holandia, Litwa, Szwecja, Portugalia i od niedawna Polska ${ }^{60}$. Głównymi dostawcami do Europy są Katar, Algieria oraz Nigeria ${ }^{61}$. Pomimo że zdolności importowe LNG na terenie UE to obecnie ok. $200 \mathrm{mld} \mathrm{m}^{3}$ (wliczając zdolności regazyfikacyjne terminalu w Świnoujściu) ${ }^{62}$, wykorzystywane są one jedynie w ok. $20 \%{ }^{63}$. Nie jest to zjawisko szczególnie nadzwyczajne na tle świata. Z reguły stopień eksploatacji mocy terminali importujących LNG waha się między 20 a 50\%. W 2015 r. współczynnik ten w skali globu wyniósł 33\%, przy czym nie uwzględniając w nim zdolności regazyfikacyjnych Stanów Zjednoczonych, które ograniczyły import na skutek rewolucji łupkowej, było to $39 \%{ }^{64}$. Uwidacznia to, że już sam fakt posiadania dodatkowego korytarza sprowadzania gazu stanowi istotną korzyść strategiczną i ważny element przewagi negocjacyjnej przy zawieraniu kontraktów na dostawy gazu, czy to drogą morską, czy lądową. Niepokój rodzi jedynie fakt, że stopień wykorzystania terminali

55 R. Zajdler, Polski rynek hurtowy gazu ziemnego..., s. 6.

2016 World LNG Report, International Gas Union, s. 20, 7, [online] http://www.igu.org/ publications/2016-world-lng-report, $15 \mathrm{~V} 2016$.

57 Tamże, s. 10, 47.

58 Aby w możliwie precyzyjny sposób przeliczyć miliony ton LNG na miliardy $\mathrm{m}^{3} \mathrm{LNG}$, należy pomnożyć wartość wyrażoną w milionach ton przez współczynnik 1,36, za: BP Statistical Review..., s. 44.

592016 World LNG Report, s. 10.

60 Terminale importowe $L N G$ sq inwestycjami strategicznymi.

61 Consultation on an EU strategy for liquefied natural gas and gas storage, European Commission, 2015, s. 2, [online] https://ec.europa.eu/energy/sites/ener/files/documents/LNG\%20consultation\%20 -\%20publication.pdf, 25 III 2016.

62 GIE LNG Map, Gas Infrastructure Europe, [online] http://www.gie.eu/index.php/maps-data/lng-map, 23 IV 2016, za: M. Gałczyński i in., Globalny rynek LNG, red. R. Zajdel, M. Ruszel, Warszawa 2015, s. 132.

63 Commission Staff working document accompanying the document: Communication from the Commission to the European Parliament, the Council, the European Economic and Social Committee and the Committee of the Regions on an EU strategy for liquefied natural gas and gas storage, European Commission, Brussels, 16 II 2016, s. 13, [online] http://eur-lex.europa.eu/legal-content/EN/TXT/ PDF/?uri=CELEX:52016SC0023\&from=pl, 25 III 2016.

64 World LNG Report - 2015 edition, International Gas Union, s. 48, [online] http://www.igu.org/sites/ default/files/node-page-field_file/IGU-World\%20LNG\%20Report-2015\%20Edition.pdf, 19 V 2016. 
regazyfikacyjnych w UE spada w stosunkowo szybkim tempie. W 2010 r. wynosił on 53\%, w 2013 r. $-25 \%{ }^{65}$. Podobny wskaźnik utrzymał się w 2015 r. (ryc. 2) ${ }^{66}$.

Ryc. 2. Zdolności importowe LNG oraz poziom ich wykorzystania w państwach UE

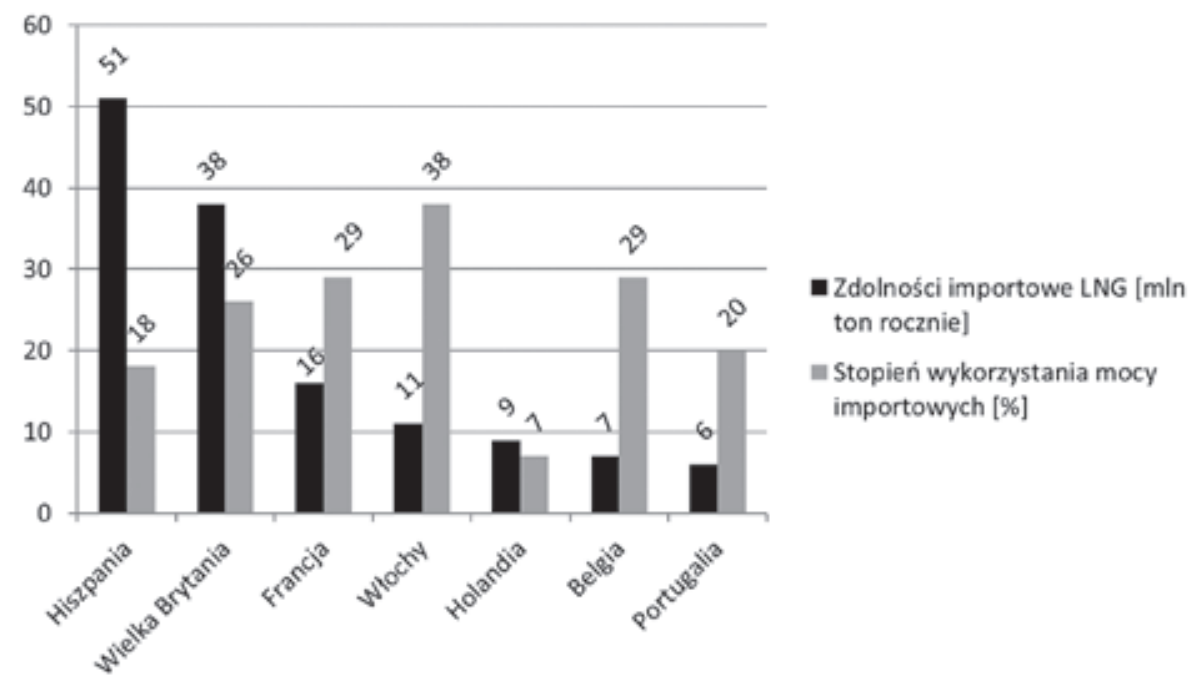

Źródło: opracowanie własne na podstawie: 2016 World NLG Report, International Gas Union, s. 47, [online] http://www.igu.org/publications/2016-world-lng-report, 19 V 2016.

Na świecie znajduje się obecnie ponad 100 instalacji LNG. Spośród państw unijnych największe zdolności posiada Hiszpania, w której ulokowanych jest siedem terminali przeznaczonych do odbioru i regazyfikacji surowca o mocy przeładunkowej na poziomie $51 \mathrm{mln}$ ton, tj. około $70 \mathrm{mld} \mathrm{m}^{367}$. Pomimo że terminale na terenie Europy przeznaczone są do odbioru surowca, a nie jego skroplenia celem eksportu, warto zauważyć, że zjawisko reeksportu również ma miejsce i, pomimo znacznego spadku w porównaniu z rokiem ubiegłym ${ }^{68}$, wyniosło w 2015 r. 3,6 mln ton $^{69}$. Państwa Europy Zachodniej, tj. Belgia, Francja, Holandia, Portugalia i Hiszpania, biorą skromny udział w odsprzedaży sprowadzonego surowca ${ }^{70}$, co oczywiście nie musi być równoznaczne z posiadaniem zdolności eksportowych LNG, gdyż transport odbywa się zazwyczaj za pośrednictwem systemu gazociągów międzysystemowych ${ }^{71}$.

\footnotetext{
Tamże, s. 50.

62016 World LNG Report, s. 48.

67 Tamże, s. 47.

68 Rok 2014 był rekordowy, jeśli chodzi o reeksport LNG na świecie i w Europie. Tamże, s. 9.

69 Tamże, s. 8.

70 Tamże.

71 Jedyny terminal przeznaczony do skraplania surowca i jego eksportu drogą morską na terenie Europy znajduje się w norweskim Snøhvit. Zob. A. Grobarčíková, J. Sosedová, T. Kalina, Development of $L N G$..., s. 35.
} 
Dla państw Dalekiego Wschodu, nieposiadających dostępu do sieci gazociągów przesyłowych, LNG stał się najbardziej opłacalnym i efektywnym rozwiązaniem. To właśnie Azja stała się największym konsumentem LNG w ostatnich latach. Ogromna luka po stronie popytowej na tym kontynencie pozytywnie wpłynęła na rozwój mocy eksportowych gazu skroplonego. Za przykład niech posłuży główny importer surowca - Japonia. Rozwiązaniem, które umożliwiło Krajowi Kwitnącej Wiśni zachowanie tempa wzrostu gospodarczego, była produkcja energii elektrycznej w oparciu o gaz ziemny i węgiel kamienny. $Z$ uwagi na ograniczenia naturalne i brak rozwiniętej infrastruktury nie był możliwy transport surowca gazociągami ${ }^{72}$. Co więcej, po katastrofie elektrowni atomowej w Fukushimie wyłączono wszystkie japońskie reaktory atomowe. Oznaczało to braki w systemie elektroenergetycznym na poziomie ok. $40 \mathrm{GW}$. Japonia, z opisanych powyżej przyczyn, stała się więc największym importerem LNG, sprowadzając w $2014 \mathrm{r}$. niemal $90 \mathrm{mln}$ ton (tj. ok. $\left.122 \mathrm{mld} \mathrm{m}^{3}\right)^{73}$. W ostatnich miesiącach rozpoczą się jednak proces przebudowy sektora produkcji energii elektrycznej. Japończycy, obawiając się spadku rozwoju gospodarczego oraz kierując się chęcią wytwarzania całkowicie ekologicznej energii w istniejących już, lecz nieeksploatowanych od czasu katastrofy w Fukushimie reaktorach atomowych, rozpoczęli uruchamianie kolejnych bloków ${ }^{74}$. W sierpniu 2015 r. włączony został reaktor Sendai 1. W październiku pracę rozpoczął Sendai 2. Wprawdzie wciąż 41 jednostek pozostaje nieczynnych, jednak zaobserwować można wyraźną tendencję do powrotu do energii atomowej ${ }^{75}$. Do końca marca $2017 \mathrm{r}$. pracować ma już 12 bloków $^{76}$. Przy ponownym rozruchu wszystkich reaktorów zapotrzebowanie Japonii na LNG spadnie o $80 \mathrm{mln}$ ton (!). Rynki azjatyckie już dyskontują to wydarzenie ${ }^{77}$. Prawdopodobnie spadający popyt w Japonii wpłynie na dalsze spadki $\operatorname{cen}^{78}$, tym bardziej że mniejsze zapotrzebowanie na gaz zgłosiła również Korea Południowa ${ }^{79}$.

72 A. Sikora, M. Sikora, $L N G$ wyrusza na poszukiwanie nowych rynków, Centrum Informacji o Rynku Energii, s. 3, [online] http://www.cire.pl/pokaz-pdf-\%252Fpliki\%252F2\%252Flng_19012016.pdf, 25 III 2016.

73 World LNG Report - 2015 edition, s. 14.

74 W. Krzyczkowski, Dzięki atomowi Japonia potrzebuje mniej LNG, Wysokie Napięcie, 28 XII 2015, [online] http://wysokienapiecie.pl/gaz-ziemny/1184-dzieki-atomowi-japonia-potrzebuje-mniej-lng, 25 III 2016.

75 World LNG Report - 2015 edition, s. 14.

76 W. Krzyczkowski, Dzięki atomowi...

77 A. Sikora, M. Sikora, $L N G$ wyrusza..., s. 3.

78 W. Krzyczkowski, Dzięki atomowi...

79 D. Malinowski, LNG dla Polski może znacznie potanieć?, Portal Gospodarczy Nowy Przemysł, 19 I 2016, [online] http://gazownictwo.wnp.pl/lng-dla-polski-moze-znacznie-potaniec,265553_1_0_0.html, 25 III 2016. 


\section{PERSPEKTYWY ROZWOJU RYNKU LNG W UNII EUROPEJSKIEJ}

\subsection{Aspekty gospodarcze}

Nie w każdym przypadku wymiana gazu transportowanego gazociągiem na LNG jest opłacalna. Gdyby tak było, obserwowalibyśmy dzisiaj odchodzenie od tradycyjnego transportu gazociągami. Przyjmuje się, że zasadnicze korzyści ekonomiczne dla zamiany gazu transportowanego tradycyjną drogą gazociągową na LNG pojawiają się w sytuacji, gdy transport surowca wymagałby budowy gazociągu lądowego o długości powyżej 5 tys. km bądź też gazociągu podmorskiego o długości większej niż 3 tys. km. W przypadku mniejszych dystansów koszty skraplania, transportu oraz regazyfikacji przewyższają profity płynące $\mathrm{z}$ handlu surowcem ${ }^{80}$.

Mechanizm kształtowania się ceny za każdą jednostkę gazu nie jest prosty. Na końcowy rezultat - sumę, jaką płaci nabywca LNG - składa się wiele czynników, zaznaczających swój pośredni lub bezpośredni wpływ. Przede wszystkim cena LNG wciąż powstaje w oparciu o jedną z mających zastosowanie formul. W przypadku rynków azjatyckich punktem odniesienia jest cena importowanej do Japonii ropy naftowej, w USA oraz Wielkiej Brytanii - rynkowa cena gazu, zaś w przypadku Europy kontynentalnej - również cena ropy, jednakże nie w aż tak wysokim stopniu jak to ma miejsce na rynkach azjatyckich ${ }^{81}$. Zauważyć jednakże należy, że od 2008 r., tj. od wybuchu kryzysu ekonomicznego oraz postępującej mniej więcej w analogicznym czasie „rewolucji łupkowej” w USA, zależność cen gazu na rynku spot ${ }^{82}$ od wartości baryłki ropy zmalała $^{83}$. Należy spodziewać się dalszego postępowania tego procesu wraz z liberalizacją rynku gazu, czego najlepszym przykładem jest Wielka Brytania, będąca prekursorem uwolnienia segmentu gazowego na Starym Kontynencie, gdzie zależność między ceną obu surowców zanikła w przeciągu kilkunastu lat ${ }^{84}$.

Nie bez znaczenia jest fakt, w jakiej walucie dochodzi do płatności za dostarczany gaz. Dla przykładu, umowa PGNiG z katarską firmą Qatargas, podobnie jak druga długoterminowa umowa polskiego przedsiębiorstwa z Gazpromem, wyrażona jest w dolarach ${ }^{85}$. Różnice kursowe mogą stanowić więc dodatni lub ujemny składnik ostatecznej ceny.

80 T. W. Kaźmierczak, Bezpieczeństwo energetyczne..., s. 95.

81 A. Szczęśniak, Światowy rynek LNG, blog autora Szczesniak.pl, 11 VI 2014, [online] http://szczesniak.pl/2676, 25 III 2016.

82 Rynek spot jest rynkiem krótkoterminowym, w sektorze energetycznym przeznaczonym głównie na zakupy interwencyjne i uzupełniające wobec dostaw wynikających z kontraktów długoterminowych.

83 L. M. Bohmer, Arbitrating international LNG disputes: lessons learned over two decades, „Journal of World Energy Law and Business" 2015, vol. 8, no. 5, s. 490, [online] DOI: 10.1093/jwelb/jwv025.

84 A. Neumann, Linking natural das markets - Is LNG doing its job?, „The Energy Journal” 2009, vol. 30, special issue: World Natural Gas Market and Trade: A Multi-Modelling Perspective, s. 188.

85 A. Sikora, M. Sikora, $L N G$ wyrusza..., s. 5. 
Jedynym państwem europejskim, w którym zaznaczył się spadek importu LNG w 2015 r., była Francja. Paryż posiada pięć terminali regazyfikacyjnych o łącznej mocy $22 \mathrm{mld} \mathrm{m}^{3}$ rocznie oraz buduje dwa kolejne, które zapewnią dodatkowe $13 \mathrm{mld} \mathrm{m}^{386}$, prawdopodobnie więc kierował się w swojej polityce aspektem cenowym. Francuski gigant energetyczny Engie posiada szeroki portfel inwestycyjny w sektorze LNG, jak też dostęp do gazociągów. Tak więc obniżenie obrotu handlowego na tym froncie należy odczytywać jako przemyślany ruch ${ }^{87}$. Dostawa LNG musiała być po prostu nieopłacalna. Istotnie, często podnoszony jest argument nieekonomiczności sprowadzania gazu droga morską wobec tańszej alternatywy w postaci surowca importowanego gazociągiem. Przedstawiciele powyższej tezy częstokroć wskazują jednak, że otwarcie nowej drogi dostaw stanowi wartość dodaną dla bezpieczeństwa energetycznego państwa, którą trudno jest wycenić w pieniądzu. Dywersyfikacja dostawców i kierunków sprowadzania gazu umożliwia renegocjację warunków cenowych długoterminowych kontraktów na dostawy rurociągami. Najlepiej zaświadcza o tym przykład Litwy. Dzięki uruchomieniu jednostki FSRU ${ }^{88}$ przedsiębiorstwu państwowemu Litgas udało się wynegocjować rabat w długoterminowej umowie na dostawy gazu zawartej z Gazpromem opiewający na 23\% ${ }^{89}$.

Przy obecnych uwarunkowaniach światowych trzeba również zauważyć, że LNG wcale nie musi być droższy od gazu sprowadzanego gazociągiem, nawet biorąc pod uwagę, że do tej pory tak właśnie było. Rok 2015 cechował się znacznym spadkiem cen LNG w porównaniu z rokiem poprzednim. Dla niektórych państw sięgały one 50\%. Spadki postępowały równolegle z ogólnoświatową obniżką cen gazu ${ }^{90}$. Ceny, jakie płaciły Wielka Brytania, Belgia i Hiszpania za LNG w dostawach spot w październiku 2015 r., oscylowały w granicach 220-240 USD/1000 $\mathrm{m}^{391}$. Zważywszy na fakt, że obecnie rosyjski Gazprom oferuje ukraińskiemu państwowemu Naftohazowi gaz po cenie $212 \mathrm{USD} / 1000 \mathrm{~m}^{3}$, zaś dostawy do Niemiec wycenianie są na 230 USD/1000 $\mathrm{m}^{392}$, można zakładać, że ceny gazu dostarczanego infrastrukturą gazociągową są jedynie nieznacznie niższe od LNG, a może nawet wyższe. Również Holandia płaci za spotowe dostawy LNG cenę zbliżoną się do tej za surowiec sprowadzany rurociaggami z Algierii oraz Norwegii ${ }^{3}$. W lutym 2016 r. cena gazu skroplonego na rynku spot dla Europy zmalała o $37 \%$ w porównaniu z grudniem 2015 r. ${ }^{94}$

86 Budowany jest terminal Dunkerque LNG, a planowany kolejny - Fos Faster LNG. Zob. tamże, s. 1.

87 Tamże, s. 1.

88 FSRU (Floating Storage Regasification Unit) - pływająca jednostka regazyfikacyjna LNG.

89 T. Loh, C. Buurma, H. Weber, American LNG exporters turn to Europe as Asian dem and sputters, Bloomberg, 22 XII 2015, [online] http://www.bloomberg.com/news/articles/2015-12-22/ american-lng-exporters-turn-to-europe-as-asian-demand-sputters, 25 III 2016.

90 R. Zajdler, LNG tańsze o potowę, LNG Snapshot, 25 XI 2015, [online] http://lngsnapshot.com/ ?p=336, 25 III 2016 .

91 Tamże.

92 Znaczne korekty dtugoterminowej prognozy, LNG Snapshot, 21 X 2015, [online] http://lngsnapshot. $\mathrm{com} /$ ?p=351, 25 III 2016.

93 Consultation on an EU strategy for liquefied natural gas..., s. 6.

94 R. Zajdler, W marcu 2016 r. ropa drożata, a gaz taniat, LNG Snapshot, 13 IV 2016, [online] http:// lngsnapshot.com/?p=437, 19 V 2016. 
Eksperci rynkowi podkreślają, że o ile przy obecnych uwarunkowaniach (niskie ceny ropy - wysokie koszty transportu metanowcami) LNG może okazać się na pierwszy rzut oka nieopłacalny (co, w nawiązaniu do treści poprzedniego akapitu, wcale nie musi być zasadą), o tyle w perspektywie długoterminowej rosnąca podaż gazu skroplonego wywrze presję na światowe ceny surowca ${ }^{95}$. W obecnie jeszcze istniejącym układzie infrastrukturalnym moc terminali skraplających szacuje się na ok. $40 \%$ mocy terminali regazyfikacyjnych, co jest zjawiskiem typowym dla rynku producenta ${ }^{96}$. Większa ilość gazu w obrocie, która coraz znaczniej przewyższa popyt (a proces ten będzie postępował na skutek ograniczenia konsumpcji LNG w Japonii), sprawia jednak, że rynek LNG staje się rynkiem importera. To dostawcy zaczynają zabiegać o znalezienie nabywców dla swojego towaru. Niezwykle atrakcyjnym kierunkiem jest dla nich Europa, gotowa zwiększyć konsumpcję gazu i stopień wykorzystania swoich instalacji, jak również promująca politykę dywersyfikacji dostaw ${ }^{97}$. Stworzenie płynnego rynku LNG zapewni więc zdecydowany wzrost konkurencyjności na rynku gazu, a co za tym idzie obniżenie cen dla importerów.

Trzeba zauważyć, że pomimo możliwości zakupu gazu skroplonego w ramach dostaw spotowych obecny rynek LNG oparty jest w dalszym ciągu na modelu kontraktów długoterminowych, najczęściej opatrzonych dodatkowo klauzulą take or pay, która nakazuje odbiorcy zakup minimalnej ilości surowca wskazanej w umowie, choćby jego bieżące zapotrzebowanie okazało się w rzeczywistości mniejsze ${ }^{98}$. Jak w większości umów długoterminowych, możliwe jest jednak renegocjowanie jej postanowień w określonych w kontrakcie okienkach negocjacyjnych. Uzasadnione jest to zwłaszcza w przypadku wahań cen gazu na rynkach światowych. Wobec postępującej globalizacji segmentu LNG połączonego z rozbudową infrastruktury oraz wzrostem konkurencji na rynku spodziewać się można większej liczby umów zawieranych w ramach kontraktów krótkoterminowych. Obecnie na rynku spot kupowane jest ok. 30\% LNG i współczynnik ten wciąż rośnie ${ }^{99}$. Jeszcze kilka lat temu długoletnie kontrakty były normą, gdyż koszty operacyjne dla dostawców gazu (zwłaszcza wyczarterowanie metanowców) były zbyt wysokie, aby gotowi byli zaryzykować zawieranie umów na pojedyncze dostawy ${ }^{100}$. W umowach zawieranych na dłuższe okresy dominowała indeksacja ceny do odpowiadającej wartości baryłki ropy ${ }^{101}$. Zbywcy LNG nie uchronili się jednak przed

95 Owoce tupkowej rewolucji ptyna do Europy, Biznes Alert, 14 I 2016, [online] http://biznesalert.pl/ owoce-lupkowej-rewolucji-plyna-do-europy/, 25 III 2016.

96 T. Tański, Funkcje Terminalu LNG..., s. 217.

97 M. Kempny, Podsumowanie, LNG Snapshot, 21 X 2015, [online] http://lngsnapshot.com/?p=347, 25 III 2016.

98 M. Ruszel, Polityczne znaczenie terminalu LNG, Energetyka24/Defence24, 8 IV 2014, [online] http://energetyka.defence24.pl/73930,polityczne-znaczenie-terminali-lng, 25 III 2016.

$99 \quad$ LNG wyraźnie zyskuje na znaczeniu, Portal Gospodarczy Nowy Przemysł, 21 VIII 2015, [online] http://gazownictwo.wnp.pl/lng-wyraznie-zyskuje-na-znaczeniu,255911_1_0_0.html, 25 III 2016.

100 T. W. Kaźmierczak, Bezpieczeństwo energetyczne..., s. 96.

101 C. Rühl, Global energy after the crisis. Prospects and priorities, „Foreign Affairs” 2010, vol. 89, no. 2, s. 72, [online] https://www.foreignaffairs.com/articles/2010-03-01/global-energy-after-crisis, 19 V 2016. 
naturalnym odruchem nabywców, którzy poszukiwali bardziej elastycznych form kontraktowania ${ }^{102}$. Obecnie sytuacja ewoluuje i w związku z tym należy spodziewać się większej liberalizacji sektora LNG. Rosnąca liczba transakcji spotowych oznacza większą konkurencyjność na rynku i niższe ceny, jak również stanowi bodziec do zainteresowania się kierunkiem europejskim eksporterów. Większy rynek spot przyczynił się do tego, że inwestorzy obecnie budują projekty LNG, nie mając uprzednio zawartych długoterminowych kontraktów gwarantujących ekonomiczne zabezpieczenie podjętych przez nich działań. W świetle aktualnych zmian na rynku nie jest to już dłużej konieczne dla zagwarantowania sobie, że uczestnicy rynku będą zawierać transakcje z wykorzystaniem stworzonej przez inwestora infrastruktury ${ }^{103}$.

Postępująca liberalizacja zapewnia również większą stabilności cenową, dzięki dokonywaniu procesu ustalania ceny na rynkach w ramach tzw. hubów ${ }^{104}$. Dzięki prostemu odniesieniu ceny zawartej w umowie sprzedaży czy dostaw LNG do ceny ukształtowanej w ramach określonego rynku spotowego utrzymuje się określony poziom pewności dla podmiotów inwestujących w $\mathrm{LNG}^{105}$. Dla rynku amerykańskiego funkcję tego pewnego rodzaju centrum dystrybucyjnego pełni Henry Hub, położony w Luizjanie, posiadający dostęp do kilkunastu gazociągów, infrastruktury LNG oraz trzech magazynów gazu w formie kawern solnych. Dzięki powyższym właściwościom od niemalże 30 lat służy jako punkt odniesienia dla nowojorskiej giełdy towarowej (NYMEX) ${ }^{106}$. W Europie podobne funkcje pełnią brytyjski NBP (National Balancing Point) oraz ARA (zespół portów morskich Amsterdam - Rotterdam - Antwerpia).

Powyższe informacje wskazują na pozytywne prognozy kształtowania się ceny LNG dla odbiorców w Europie. Prawdopodobnie cena ta będzie w najbliższych kilku latach bardzo zbliżona do sum płaconych $\mathrm{w}$ istniejących kontraktach $\mathrm{z}$ dostawcami dostarczającymi surowiec drogą gazociągową. Może to mieć kluczowe znaczenie dla państw Europy Środkowo-Wschodniej, które do tej pory płaciły nieproporcjonalnie wysokie sumy za gaz kupowany od Rosji. Zauważa się również, że zwiększenie liczby terminali LNG wpłynie korzystnie na konkurencyjność rynku energii, przyczyniając się do zwiększenia ilości ofert kompleksowych ${ }^{107}$, co będzie dodatnim bodźcem do intensyfikacji wykorzystania skroplonego gazu w przemyśle $e^{108}$. Wskazuje się również, że transportowanie gazu metanowcami jest kilkukrotnie tańsze niż np. sama budowa kilkusetkilometrowego gazociągu. Koszty budowy terminalu LNG w Świnoujściu wynio-

102 J. Baily, R. Lidgate, $L N G$ price reviews..., s. 152.

103 D. L. Brito, P. R. Hartley, Expectations and the evolving world gas market, „The Energy Journal” 2007, vol. 28, no. 1, s. 2, 23 .

104 Hub to wirtualny bądź fizyczny punkt sprzedaży gazu, mający wymierny wpływ na kształtowanie cen na rynku. Częstokroć o jego wartości dla ustalania ceny surowców decyduje odpowiednie położenie geograficzne, zwłaszcza w punkcie przecięcia sieci przesyłowych, umożliwiające łączenie rynków, a także rozbudowana infrastruktura magazynowa.

105 L. M. Bohmer, Arbitrating international LNG disputes..., s. 490.

106 A. Neumann, Linking natural gas markets..., s. 189.

107 Oferta kompleksowa zawiera w sobie zarówno sprzedaż gazu, jak i jego dostarczenie do odbiorcy. 
sły ok. 3 mld zł109. Litwa, korzystająca z dziesięcioletniej dzierżawy terminala pływającego FSRU, rocznie przekazuje na rzecz wydzierżawiającego kwotę ok. $69 \mathrm{mln} \mathrm{USD}^{110}$. Dla porównania, koszt budowy gazociągu Baltic Pipe, który mógłby połączyć Danię i Polskę, Gazprom szacuje na 10 mld USD ${ }^{111}$. Nawet zakładając, że są to szacunki zawyżone o 2-3 mld USD (koszty dużo poważniejszej inwestycji, jaką jest Nord Stream II, szacowane są na 9,9 mld Euro ${ }^{112}$, tj. ok. 11 mld USD), i tak pozostaje to relatywnie wysoką kwotą wobec wydatków poniesionych na inwestycję w terminal LNG.

Ponadto wykorzystanie LNG umożliwia elastyczne dobieranie dostawy surowca od podmiotu proponującego najlepsze warunki i pozwala na prowadzenie interwencyjnych zakupów gazu nawet z państw odległych ${ }^{113}$. Postępująca liberalizacja sektora gazowego, w tym również zwiększone obroty międzynarodowe LNG, doprowadzi w dalszej perspektywie do ujednolicenia poziomu cen w skali globu ${ }^{114}$, co stworzy bardziej pewne warunki dla inwestorów oraz podmiotów dokonujących obrotu surowcem.

\subsection{Aspekty polityczne}

Niejednokrotnie w literaturze traktującej o polityce energetycznej podnosi się, że nie zawsze strategia zaopatrzenia państwa w niezbędne surowce oparta musi być na zapewnieniu jak najniższej ceny. Częstokroć celem przeprowadzenia kosztochłonnych inwestycji jest osiągnięcie jak najwyższego stanu bezpieczeństwa energetycznego. Trudno jest wycenić tę wartość w pieniądzu. Aspekt ten jest szczególnie istotny dla państw uzależnionych od dostaw z jednego kierunku w ponad 40\%. Przykładów nie trzeba daleko szukać. W Europie są to: Bułgaria, Chorwacja, Czechy, państwa bałtyckie, Finlandia, Węgry, Rumunia, Słowacja czy Słowenia. Kwestia ta nie jest obojętna również dla państw takich jak Włochy, Francja czy Niemcy, gdyż w dużej mierze opierają one swoją gospodarkę na dostawach gazu ze Wschodu i wszelkie przerwy w jego imporcie przekraczające kilka dni będą skutkowały milionowymi stratami. Import LNG umożliwia stworzenie nowych korytarzy dostaw, co pozwala zagwarantować bezpieczniejsze zaopatrzenie w gaz, a dodatkowo pozytywnie wpływa na pozycję negocjacyjną państwa

109 Inwestycje energetyczne - terminal LNG, Ministerstwo Skarbu Państwa, [online] http://www. msp.gov.pl/pl/nauka-i-rozwoj/projekty-strategiczne/inwestycje-energetyczne/inwestycje-energetyczn/24508,Terminal-LNG.html, 25 III 2016.

110 W. Jakóbik, Litwa chciataby wczé́niejszego wykupu FSRU $z$ dzierżawy, Centrum Informacji o Rynku Energii, 14 VIII 2015, [online] http://www.cire.pl/item,115658,1,0,0,0,0,0,litwa-chcialaby-wczesniejszego-wykupu-fsru-z-dzierzawy.html, 25 III 2016.

111 Budowa polsko-duńskiego gazociagu „Baltic Pipe” już za cztery lata, Polskie Radio, 21 III 2015, [online] http://www.polskieradio.pl/5/3/Artykul/1597623,Budowa-polsko-dunskiego-gazociagu-Baltic-Pipe-juz-za-cztery-lata, 25 III 2016.

112 A. Loskot-Strachota, The case against Nord Stream II, Energy Post, 23 XI 2015, [online] http://www. energypost.eu/case-nord-stream-2/, 25 III 2016.

113 T. W. Kaźmierczak, Bezpieczeństwo energetyczne..., s. 89-90.

114 J. Deutch, The good news about gas: the natural gas revolution and its consequences, „Foreign Affairs” 2011, vol. 90, no. 1, s. 88, [online] https://www.foreignaffairs.com/articles/2011-01-01/good-news-about-gas, 19 V 2016. 
$\mathrm{w}$ relacjach handlowych z dostawcami korzystającymi z tranzytu rurociągami. Budowa infrastruktury LNG bardzo często ma ex ante za zadanie zapewnić bezpieczeństwo dostaw, a nie gwarancję przychodu ${ }^{115}$. Im więcej punktów wejścia do systemu gazowego danego państwa, tym mniejsze ryzyko zakłóceń dostaw gazu ${ }^{116}$. Znaczenie terminali może wszak szczególnie wzrosnąć w sytuacji przerwania dostaw gazociągami z jakichkolwiek przyczyn. Państwa posiadające infrastrukturę LNG znajdą się wtedy na korzystnej pozycji ${ }^{117}$.

Wskazując na atuty LNG, trzeba zauważyć,że transport morski jest dużo mniej podatny na wahania koniunktury politycznej - zapewnienie bezpiecznego transportu wymaga przede wszystkim zachowania dobrych relacji z państwem eksportującym surowiec, nie ma konieczności brania pod uwagę czynników ryzyka w postaci sytuacji politycznej państw, przez które przebiega tranzyt ${ }^{118}$. Owszem, istnieje ryzyko ataku terrorystycznego czy aktywności pirackiej wobec metanowców czy infrastruktury przeładunkowej, zwłaszcza że LNG sprowadzany jest również szlakiem biegnącym wzdłuż kontynentu afrykańskiego. Do dzisiaj jednak nie odnotowano poważniejszych zakłóceń tego typu w transporcie. Częstokroć dostawcy korzystają również z usług firm ochroniarskich.

Polityczny aspekt dostaw LNG jest w przypadku Europy szczególnie istotny. Problem zaopatrzenia w gaz jest bowiem traktowany, zwłaszcza w Europie Środkowo-Wschodniej, jako problem o charakterze właśnie politycznym. Budowa terminali LNG oraz połączeń międzysystemowych zapewnia polityczną niezależność wielu państwom UE zdanym do tej pory na jeden główny kierunek dostaw i niejednokrotnie poddawanym naciskom politycznym ze strony głównego dostawcy. Zauważa się jednak również negatywną zależność w postaci mniejszej skłonności do rozbudowy połączeń międzysystemowych pomiędzy państwami posiadającymi terminale importowe LNG celem „dzielenia się" gazem ${ }^{119}$. Jest to element, na którym winna skupić się Unia Europejska, tak aby międzynarodowe przepływy surowca nie były hamowane przez braki w infrastrukturze.

\subsection{Aspekty prawne}

Sektor energetyczny poddany jest ścisłej regulacji prawnej. UE wydała w ostatnich kilkunastu latach wiele aktów prawnych odnośnie do rynku gazu ziemnego, poświęcając uwagę m.in. zwalczaniu problemów niskiego stopnia dywersyfikacji źródeł dostaw w państwach członkowskich, jak i zbyt małej liczbie połączeń międzysystemowych.

Akty prawa pierwotnego nie zawierają szczególnej regulacji dla LNG, a tworzą dla niego jedynie pewne ogólne ramy ${ }^{120}$. Traktat o funkcjonowaniu Unii Europejskiej

\footnotetext{
115 Terminale importowe $L N G$ sa inwestycjami strategicznymi.

116 M. Ruszel, Znaczenie terminali $L N G$..., s. 54.

117 Tamże.

118 T. W. Kaźmierczak, Bezpieczeństwo energetyczne..., s. 89-90.

119 M. Ruszel, Znaczenie terminali $L N G$..., s. 54.

120 M. Gałczyński i in., Globalny rynek LNG, s. 61-62.
} 
(Dz. Urz. UE C 326 z 26 października 2012 r.) w kluczowym art. 194 wprowadził odrębną politykę w zakresie energii, której priorytetami są m.in. zapewnienie funkcjonowania rynku energii, bezpieczeństwa dostaw i wspierania wzajemnych połączeń między sieciami, co odnieść można do LNG ${ }^{121}$.

Kluczowe dokumenty w zakresie rynku gazu w Europie stanowią regulacje składające się na tzw. trzeci pakiet energetyczny. Poprzednio obowiązujące: pierwszy oraz drugi pakiet, wdrażane odpowiednio od 1998 oraz 2003 r., straciły nieco na aktualności. Ponadto rozwój rynku wymógł wprowadzenie nowych rozwiązań. Weszły więc w życie m.in. Rozporzadzenie Parlamentu Europejskiego i Rady (WE) nr 715/2009 z 13 lipca 2009 r. w sprawie warunków dostępu do sieci przesytowej gazu ziemnego oraz Dyrektywa Parlamentu Europejskiego i Rady 2009/73/WE z 13 lipca 2009 r. dotyczaca wspólnych zasad rynku wewnętrznego gazu ziemnego.

Podstawową zmianą wynikającą z dyrektywy było wprowadzenie wymogu rozdziału działalności w zakresie przesyłu, dystrybucji oraz magazynowania gazu w każdym państwie członkowskim. Od tej pory w każdym z wskazanych podsektorów występować miał wydzielony, przynajmniej pod względem prawnym, operator systemu odpowiednio: przesyłowego, dystrybucyjnego, magazynowania oraz operatora systemu $\mathrm{LNG}^{122}$. W praktyce największe znaczenie, z punktu widzenia zapewnienia przepływów surowca, ma ten pierwszy. Każde państwo wyznacza operatora, bądź operatorów ${ }^{123}$, systemu przesyłowego, będącego albo właścicielem gazociągów przesyłowych ${ }^{124}$, albo ich niezależnym operatorem. Każdy z operatorów poszczególnych systemów obowiązany jest do udostępniania swojej infrastruktury na prawnie określonych warunkach bez nieuzasadnionej dyskryminacji (zasada TPA). Wynika to z faktu, że dysponowanie przez nich stosownymi instalacjami magazynowymi, przesyłowymi czy regazyfikacyjnymi nosi znamiona posiadania monopolu naturalnego, tj. z reguły za pomocą jedynie konkretnie wskazanej infrastruktury jest możliwe świadczenie usług o charakterze publicznym. Nie jest bowiem uzasadniona ekonomicznie budowa np. kolejnych zajmujących sporą

121 Tamże, s. 64-65.

122 W świetle dyrektywy 2009/73 dotyczącej zasad wewnętrznego rynku gazu operator systemu LNG to osoba fizyczna lub prawna, która zajmuje się skraplaniem gazu ziemnego lub jego przywozem, wytadunkiem i regazyfikacją LNG oraz jest odpowiedzialna za eksploatację instalacji LNG (art. 2 pkt 12). Instalacja ta $\mathrm{z}$ kolei zdefiniowana została jako terminal wykorzystywany do skraplania gazu ziemnego lub importu, wytadunku i regazyfikacji LNG i który obejmuje ustugi pomocnicze i buforowe zbiorniki magazynowe niezbędne do procesu regazyfikacji, a następnie dostarczania gazu do systemu przesytowego, ale z wytaczeniem wszelkich części terminali LNG, które przeznaczone sa do magazynowania (art. 2 pkt 11). Dyrektywa Parlamentu Europejskiego i Rady 2009/73/WE z dnia 13 lipca 2009 r. dotycząca wspólnych zasad rynku wewnętrznego gazu ziemnego i uchylająca dyrektywę 2003/55/WE, Dz.Urz. UE L 211 z 14 VIII 2009 r., [online] http://eur-lex.europa.eu/legal-content/PL/TXT/ PDF/?uri=CELEX:32009L0073\&from=PL, 29 III 2016.

123 Na gruncie polskiego prawa funkcjonować może tylko jeden operator systemu przesyłowego. Zob. art. 9 h ust. 2 Ustawy z dnia 10 kwietnia 1997 r. Prawo energetyczne, Dz.U. 1997, nr 54, poz. 348 z późn. $z m$.

124 Gazociągi przesyłowe to gazociągi o największej przepustowości, umożliwiające import i eksport gazu oraz rozprowadzenie do sieci dystrybucyjnych w celu dostarczenia go odbiorcom wewnętrznym. 
powierzchnię gazociągów przesyłowych przez sprzedawców gazu, skoro operator sieci może udostępnić im swoje zdolności przesyłowe za stosowną opłatą określoną w taryfie. Analogiczne zasady dotyczą instalacji LNG, do której zgodnie z treścią dyrektywy zalicza się również usługi pomocnicze i buforowe zbiorniki magazynowania. Zdaniem części ekspertów uzasadniony jest postulat rozszerzenia zakresu definicji na część instalacji przeznaczoną jest do magazynowania gazu ziemnego, które obecnie mieszczą się w odrębnej definicji magazynowania ${ }^{125}$. Dla terminala LNG w Świnoujściu funkcję operatora pełni spółka Polskie LNG S.A. wydzielona ze spółki operatora systemu przesyłowego gazu, tj. OGP Gaz-System S.A. Operator (lub operatorzy ${ }^{126}$ ) instalacji LNG wyznaczani są przez państwo członkowskie ${ }^{127}$ na czas określony, zapewniają dostęp do swojej instalacji podmiotom trzecim na zasadzie regulowanej (rTPA), a więc na podstawie zatwierdzonych przez organ regulacyjny taryf, przy czym operator jest obowiązany do takiego ukształtowania świadczonych usług, aby odpowiadały one zapotrzebowaniu rynkowemu oraz współdziałały z systemem połączeń międzysystemowych, przy zachowaniu niedyskryminacyjnych warunków dla uczestników rynku (tj. odbiorców, przedsiębiorstw obrotu) ${ }^{128}$.

Kolejnym ważnym aktem jest rozporządzenie w sprawie środków zapewniających bezpieczeństwo dostaw gazu ziemnego nr 994/2010 z dnia 20 października 2009 r. (tzw. rozporządzenie SoS). Przepisy nakładają na państwa członkowskie obowiązek wdrożenia mechanizmu reagowania w sytuacji przerwania dostaw gazu. W tym celu wprowadzone są trzy stopnie zagrożenia: „stan wczesnego ostrzegania”, „stan alarmowy”, „stan nadzwyczajny” ${ }^{29}$. W sytuacji kryzysowej państwa obowiązane są udostępnić swoje zdolności przesyłowe oraz magazynowe, Komisja zaś na wniosek co najmniej dwóch państw, w których nastąpił stan zagrożenia, podejmuje działania mające na celu zapewnienie spójności i koordynacji działań w skali regio-

125 M. Gałczyński i in., Globalny rynek LNG, s. 67.

126 Zdaniem R. Zajdlera z uwagi na to, że obecnie większość państw unijnych wyodrębniła więcej niż jednego operatora systemu LNG, jak również biorąc pod uwagę kierunek rozwoju rynku gazu w UE, należy się spodziewać wyłączenia w przyszłości możliwości wyznaczania tylko jednego operatora przez państwa członkowskie. R. Zajdler, Komentarz do dyrektywy Parlamentu Europejskiego i Rady 2009/72/WE z dnia 13 lipca 2009 r. dotyczacej wspólnych zasad rynku wewnętrznego energii elektrycznej i uchylajacej dyrektywe 2003/54/WE (Dz.U.UE.L.09.211.55), LEX/el., 2011, art. 12, [online] http://lex.adm.uj.edu.pl/lex/index.rpc?\&fromHistory=false\#content.rpc-ASK-nro= $201335083 \&$ wersja $=0 \&$ local $N$ roPart $=587300583 \&$ full TextQuery.query $=2003 \% 252 \mathrm{~F} 55 \&$ reqI $\mathrm{d}=1461400800806 \_1046599685 \&$ class $=$ CONTENT\&loc $=4 \&$ full $=1 \& \mathrm{hId}=2,19 \mathrm{~V} 2016$.

Możliwa jest również implementacja procedury, zgodnie z którą wyznaczeniem operatora LNG zajmują się przedsiębiorstwa gazowe będące właścicielami instalacji LNG, a ich decyzja podlega następczemu zatwierdzeniu przez organ regulacyjny. M. Gałczyński i in., Globalny rynek LNG, s. 68.

128 Tamże, s. 67-70.

129 Art. 10 ust. 3 Rozporzadzenia Parlamentu Europejskiego i Rady (UE) nr 994/2010 z dnia 20 października 2009 r. w sprawie środków zapewniajacych bezpieczeństwo dostaw gazu ziemnego i uchylenia dyrektywy Rady 2004/67/WE [rozporządzenie SoS], Dz.Urz. UE L 295 z 12 XI 2010 r., [online] http://eur-lex.europa.eu/legal-content/PL/TXT/PDF/?uri=CELEX:32010R0994\&from=PL, 29 III 2016. 
nalnej ${ }^{130}$. Wewnątrzpaństwowe organy regulacyjne (w Polsce jest to Urząd Regulacji Energetyki), działając na bazie dyrektywy, wspólnie przygotowują plany działań zapobiegawczych (Preventive Action Plans) oraz plany działania na wypadek sytuacji nadzwyczajnych (Emergency Plans) ${ }^{131}$.

Zauważyć należy, że obecne uregulowania prawne nie biorą pod uwagę w odpowiednim stopniu korzyści o charakterze strategicznym płynących z LNG. Wskazane jest większe uwzględnienie nieograniczonych możliwości dostaw wobec wyczerpywalnych rezerw obowiązkowych, jak i elastycznego reagowania na deficyt surowca, wynikających ze specyfiki rynku spotowego $\mathrm{LNG}^{132}$. W ramach zimowego pakietu gazowego Komisji Europejskiej z lutego 2016 r. zaproponowany został nowy kształt rozporządzenia SoS. Miałoby ono uwzględniać w większym stopniu problematykę efektywnego korzystania $\mathrm{z}$ infrastruktury regazyfikacyjnej oraz magazynowej, zarówno w warunkach rynkowych, jak i sytuacjach nadzwyczajnych ${ }^{133}$. Proponuje bowiem przygotowywanie oceny ryzyka, planów działań zapobiegawczych i planów działania na wypadek sytuacji nadzwyczajnych na poziomie regionalnym ${ }^{134}$ (Polska znalazłaby się w jednym regionie z Niemcami, Słowacją i Czechami) ${ }^{135}$, wdrożenie płynniejszego systemu wymiany informacji między państwami podczas zagrożenia dostaw ${ }^{136}$, efektywniejsze uregulowanie wskaźnika N-1 ${ }^{137}$ oraz zdolności przepływu gazu w obu kierunkach na gazocią-

130 Art. 11 ust. 1 rozporządzenia SoS.

131 Rozporządzenie w sprawie środków zapewniających bezpieczeństwo dostaw gazu ziemnego, Urząd Regulacji Energetyki, 12X2012, [online] http://www.ure.gov.pl/pl/urzad/wspolpraca-miedzynarod/ inne-akty-prawne-ue/4949, Rozporzadzenie-w-sprawie-srodkow-zapewniajacych-bezpieczenstwo-dostaw-gazu-ziemn.html, 25 III 2016.

132 M. Gałczyński i in., Globalny rynek LNG, s. 74-75.

133 Communication from the Commission to the European Parliament, the Council, the European Economic and Social Committee and the Committee of the Regions on an EU strategy for liquefied natural gas and gas storage, European Commission, Brussels, 16 II 2016, s. 10, [online] https://ec.europa.eu/energy/ sites/ener/files/documents/1_EN_ACT_part1_v10-1.pdf, 25 III 2016.

134 Wniosek - Rozporzadzenie Parlamentu Europejskiego i Rady dotyczace środków zapewniajacych bezpieczeństwo dostaw gazu ziemnego i uchylające rozporzadzenie (UE) nr 994/2010, Komisja Europejska, Bruksela, 16 II 2016, s. 30, 32, [online] http://eur-lex.europa.eu/legal-content/PL/TXT/ HTML/?uri=CELEX:52016PC0052\&from=EN, 26 III 2016.

135 Koncepcja budowy wewnętrznego płynnego rynku gazu z wykorzystaniem regionów winna być gruntownie przemyślana. Wątpliwości budzi umieszczenie w jednym koszyku państw Niemiec, które potencjalnie mogłyby zwiększać stopień swojego bezpieczeństwa przez czerpanie korzyści z wykorzystania LNG kosztem bardziej uzależnionych od dostaw z Rosji państw Grupy Wyszehradzkiej. Nie jest również wskazane tworzenie zbyt obszernego i niejednorodnego regionu, który pierwotnie proponował ENTSO-G (Europejska Sieć Operatorów Systemów Przesyłowych Gazu), składającego się z Niemiec, Polski, Austrii, Czech, Słowacji, Chorwacji, Rumunii i Bułgarii. M. Gałczyński i in., Globalny rynek $L N G$, s. 51.

136 Wniosek - Rozporządzenie Parlamentu Europejskiego i Rady dotyczące środków zapewniajacych bezpieczeństwo dostaw gazu ziemnego i uchylające rozporzadzenie (UE) nr 994/2010, s. 41-43.

137 Wskaźnik N-1 ocenia zdolność zaopatrzenia w gaz ziemny przy wytaczeniu gtównego źródta dostaw. Parametrami stużacymi wyliczeniu wartości tego wskaźnika są zdolnośćtechniczna punktów wejścia, zdolność produkcyjna, zdolność odbioru gazu ziemnego znajdującego się w magazynach oraz zdolność importowa terminali $L N G$, które po zsumowaniu i pomniejszeniu o zdolności gtównego źródta porównywane sa 
gach międzysystemowych (LNG miałby być wyłączony z tego obowiązku) ${ }^{138}$, jak również rozszerzenie stosowania dyrektywy na państwa prowadzące dialog w ramach unii energetycznej $^{139}$ (tj. na państwa bałkańskie, Mołdawię oraz Ukrainę ${ }^{140}$ ). Dodatkowo postuluje wprowadzenie mechanizmu solidarnościowego, opartego na zasadzie pomocy w stanie nadzwyczajnym odbiorcy chronionemu ${ }^{141} \mathrm{w}$ sąsiadującym państwie członkowskim, nawet kosztem zaopatrzenia w surowiec własnych obywateli, o ile nie kwalifikują się do grupy odbiorców chronionych ${ }^{142}$.

W obrocie prawnym funkcjonuje również Rozporządzenie Parlamentu Europejskiego $i$ Rady (UE) z dnia 17 kwietnia 2013 r. w sprawie wytycznych dotyczacych transeuropejskiej infrastruktury energetycznej (tzw. rozporządzenie w sprawie TEN-E). Projekt ten daje podstawy prawne do tworzenia regionalnych list projektów wspólnego zainteresowania (tzw. Projects of Common Interest - PCI). Po otrzymaniu takiego statusu inwestycje mogą liczyć na dofinansowanie z programu „Łącząc Europę” (Connecting Europe Facility - CEF). W budżecie zaplanowanym na lata 2014-2020 planuje się przeznaczenie 5,35 mld euro ${ }^{143} \mathrm{~m}$.in. na projekty terminali LNG oraz związanych z nimi sieci przesyłowych, które to projekty w większości otrzymały status PCI.

Warto wspomnieć również o Rozporzadzeniu Parlamentu Europejskiego i Rady (UE) nr 1227/2011 z dnia 25 października 2011 r. w sprawie integralności i przejrzystości hurtowego rynku energii (tzw. REMIT). Jego treść zobowiązuje podmioty dokonujące obrotu energią, jak również udostępniające zdolności przesyłowe gazu ziemnego do raportowania zawartych transakcji ${ }^{144}$, podawania informacji wewnętrz-

maksymalna dzienna konsumpcją. R. Zajdler, Zajdler: Rozporządzenie SoS czyli jak uszczelnić bezpieczeństwo gazowe UE, Biznes Alert, 12 II 2015, [online] http://biznesalert.pl/zajdler-rozporzadzenie-sos-czyli-jak-uszczelnic-bezpieczenstwo-gazowe-unii-energetycznej/, 26 III 2016.

138 Wniosek - Rozporządzenie Parlamentu Europejskiego i Rady dotyczace środków zapewniajacych bezpieczeństwo dostaw gazu ziemnego i uchylające rozporządzenie (UE) nr 994/2010, s. 11, 27.

139 Tamże, s. 13.

140 J. Dudek, Czy uda się uratować Unię energetyczna??, Centrum Analiz Klubu Jagiellońskiego, 21 II 2016, [online] http://cakj.pl/2016/02/21/czy-uda-sie-uratowac-unie-energetyczna, 26 III 2016.

141 Odbiorcą chronionym jest małe lub średnie przedsiębiorstwo, pod warunkiem że jest podłączone do sieci dystrybucyjnej gazu, lub podmiot świadczący podstawowe usługi społeczne (świadczenia opieki zdrowotnej oraz służby ratunkowe i bezpieczeństwa), jak również instalacja systemów ciepłowniczych, o ile dostarcza energię cieplną gospodarstwom domowym, małym i średnim przedsiębiorstwom oraz podmiotom świadczącym podstawowe usługi społeczne. Wniosek - Rozporządzenie Parlamentu Europejskiego i Rady dotyczące środków zapewniajacych bezpieczeństwo dostaw gazu ziemnego i uchylajace rozporzadzenie (UE) nr 994/2010.

142 Wniosek - Rozporządzenie Parlamentu Europejskiego i Rady dotyczace środków zapewniajacych bezpieczeństwo dostaw gazu ziemnego i uchylające rozporządzenie (UE) nr 994/2010, s. 13, 40-41.

143 M. Vella, Gas pipeline retains EU status for future funding, „Malta Today” 2015, 18 XI, [online] http:// www.maltatoday.com.mt/news/national/59395/gas_pipeline_retains_eu_status_for_future_funding, 25 III 2016.

144 Art. 8 Rozporządzenia Parlamentu Europejskiego i Rady (UE) nr 1227/2011 z dnia 25 października 2011 r. w sprawie integralności i przejrzystości hurtowego rynku energii [REMIT], Dz.Urz. UE L 326 z 8 XII 2011 r., [online] http://eur-lex.europa.eu/legal-content/PL/TXT/PDF/?uri= CELEX:32011R1227\&from=PL, 29 III 2016. 
nych ${ }^{145}$ do wiadomości publicznej, a także zabrania im dokonywania manipulacji na rynku hurtowym ${ }^{146}$ oraz niewłaściwego wykorzystywania informacji wewnętrznych ${ }^{147}$. Sprowadza się to do wymogu upubliczniania podejmowanych operacji handlowych, a w przypadku podmiotów zarządzających instalacjami LNG - danych dotyczących zdolności oraz wykorzystania tych instalacji, a także planowanej i nieplanowanej niedostępności instalacji ${ }^{148}$.

Istotnym uregulowaniem, również z punktu widzenia dostaw LNG, jest Decyzja Parlamentu Europejskiego i Rady nr 994/2012/UE w sprawie ustanowienia mechanizmu wymiany informacji w odniesieniu do umów międzyrządowych $w$ dziedzinie energii między państwami cztonkowskimi a państwami trzecimi (tzw. decyzja IGA - Inter-Governmental Agreements). Na jej mocy państwa członkowskie przedstawiają Komisji obowiązujące umowy międzyrządowe wraz z załącznikami i zmianami tych umów w zakresie, w jakim mają wptyw na dziatanie lub funkcjonowanie rynku wewnętrznego energii bądź na bezpieczensstwo dostaw energii $w$ Unii ${ }^{149}$. W ramach pakietu zimowego Komisja zaproponowała nową treść rozporządzenia, zakładającą obowiązek przedkładania jej umów międzyrządowych ex ante, przed jej podpisaniem, a nie expost - jak to miało miejsce do tej pory. Udział Komisji w ocenie umowy rozpoczynałby się już na etapie jej negocjowania, o którym miałaby być ona informowana. Tak jak poprzednio, obowiązek taki nie objątby umów komercyjnych między przedsiębiorstwami (choć można je poddać ocenie Komisji pod kątem zgodności z prawem unijnym na zasadzie dobrowolności $)^{150}$.

Regulacje prawne mają na celu zagwarantować jednolitość przepisów na terenie Unii, uczciwą konkurencję oraz bezpieczeństwo energetyczne. Jest to istotne dla skoordynowanego przebiegu procesów inwestycyjnych. Komisja Europejska wskazuje na brak implementacji trzeciego pakietu energetycznego jako istotny czynnik hamujący inwestycje w sektorze LNG ${ }^{151}$. Należy zgodzić się z powyższym twierdzeniem i wskazać, że problemem nie jest dzisiaj brak odpowiednich instrumentów prawnych, lecz niewystarczające egzekwowanie obowiązujących przepisów. UE powinna więc z większą stanowczością wymagać respektowania założeń trzeciego pakietu liberalizacyjnego,

145 Informacja wewnętrzna to, w świetle rozporządzenia, informacja o szczegółowym charakterze, która - po podaniu do publicznej wiadomości - mogłaby w sposób znaczący wpłynąć na ceny produktów energetycznych sprzedawanych na rynku hurtowym.

146 Art. 5 REMIT.

147 Art. 3 ust. 1 REMIT.

148 Art. 4 ust. 1 REMIT.

149 Art. 2 pkt 1, art. 3 ust. 1 Decyzji Parlamentu Europejskiego i Rady nr 994/2012/UE z dnia 25 października 2012 r. $w$ sprawie ustanowienia mechanizmu wymiany informacji $w$ odniesieniu do umów międzyrządowych $w$ dziedzinie energii między panstwami cztonkowskimi a państwami trzecimi [IGA], Dz.Urz. UE L 299 z 27 X 2012 r., [online] http://eur-lex.europa.eu/legal-content/PL/TXT/ PDF/?uri=CELEX:32012D0994\&from=PL, 29 III 2016.

150 Wniosek - Decyzja Parlamentu Europejskiego i Rady w sprawie ustanowienia mechanizmu wymiany informacji w odniesieniu do umów międzyrządowych $w$ dziedzinie energii między państwami cztonkowskimi a państwami trzecimi i uchylająca decyzje nr 994/2012/UE, Komisja Europejska, Bruksela, 16 II 2016, s. 7-8, [online] https://ec.europa.eu/transparency/regdoc/rep/1/2016/PL/1-2016-53-PL-F1-1.PDF, 26 III 2016.

151 Consultation on an EU strategy for liquefied natural gas..., s. 5. 
szczególnie zasady TPA, i dopilnować jego pełnego wdrożenia do systemów prawnych państw członkowskich. Równolegle powinno być prowadzone planowanie strategiczne na poziomie politycznym, gdyż bez niego przepisy ułatwiające rozwój infrastruktury i obrotu LNG nie spełnią swojej roli. Równocześnie należy pozytywnie ocenić propozycję nowej treści rozporządzenia SoS. Zwiększenie roli planowania regionalnego w zapewnieniu bezpieczeństwa gazowego może stanowić dodatni impuls dla działań mających na celu zwiększenie bezpieczeństwa gazowego UE.

\subsection{Aspekty infrastrukturalne}

Rynek LNG nie istnieje bez infrastruktury. Bez niej nie dojdzie do stworzenia rynków regionalnych, które w dalszym ciągu tworzą potencjał budowania jednolitego rynku europejskiego. Znajdujące się obecnie na etapie budowy bądź projektowania instalacje związane z LNG to m.in.: 152

- terminal Independent w Aleksandropolis w Grecji (zdolności regazyfikacyjne: 6,1 $\mathrm{mld} \mathrm{m}^{3}$, zdolności magazynowe: 170 tys. $\mathrm{m}^{3}$, planowane oddanie do użytku: $\left.2018^{153}\right)$;

- terminal egejski w okolicach Kawali - również w Grecji (terminal FSRU, planowane zdolności regazyfikacyjne: $3-5 \mathrm{mld}^{3}$, zdolności magazynowe: 150 tys. $\mathrm{m}^{3154}$;

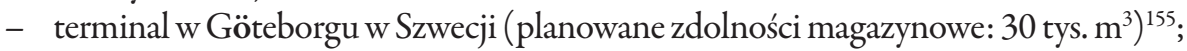

- projektowany terminal w Konstancy w Rumunii;

- projektowany terminal bałtycki w Finlandii;

- projektowany mały terminal dystrybucyjny przeznaczony do bunkrowania w Estonii (zamierzona zdolność magazynowa: 90 tys. m³ $)^{156}$;

- BalticConnector - projekt gazociągu między Finlandią a Estonią (planowana przepustowość: 2,6 mld m³ , planowane oddanie do użytku: 2020) ${ }^{157}$, którego praca mogłaby zostać skoordynowana $\mathrm{z}$ funkcjonowaniem projektowanych terminali Paldiski oraz Tallin (u wybrzeży odpowiednio: Finlandii i Estonii) ${ }^{158}$;

- terminal na wyspie Krk w Chorwacji, który ma umożliwić „domknięcie” ko-

\section{Tamże, s. 3-4}

The Project, Gastrade S.A., [online] http://www.gastrade.gr/en/the-company/the-project.aspx, 19 V 2016.

Aegean LNG - Studies related to permitting procedure, European Commission, I 2016, [online] https://ec.europa.eu/inea/sites/inea/files/fiche_6.9.2-0008-el-s-m-14_final_0.pdf, 25 III 2016.

Construction at the energy port, LNG-Terminal Gothenburg, [online] http://www.swedegas.com/ Home/LNG_terminal/lng_terminal/go4lng_project/ny-infrastruktur, 25 III 2016.

156 L. Jegelevicius, Estonia's LNG plans hit reality check, Natural Gas Europe, 8 II 2016, [online] http:// www.naturalgaseurope.com/estonia-tallinn-lng-terminal-prospects-dampened-revised-lithuania-statoil-contract-28030, 25 III 2016.

157 Baltic Connector will end isolation of Finnish gas market and complete Baltic Gas Ring, European Commission. Energy, 22 XII 2015, [online] https://ec.europa.eu/energy/en/news/balticconnector-will-end-isolation-finnish-gas-market-and-complete-baltic-gas-ring, 25 III 2016. 
rytarza Północ-Południe, tj. sieci przesyłu gazu przez państwa Grupy Wyszehradzkiej oraz Chorwację, zwieńczonego już na północnym ,wierzchołku” będącym w trakcie uruchamiania komercyjnych dostaw gazoportem w Świnoujściu (planowana przepustowość: 4-6 $\mathrm{mld} \mathrm{m}^{3}$, zdolności magazynowe: 2 x 180 tys. $\mathrm{m}^{3}$, data oddania do użytku: 2019) ${ }^{159}$.

W maju 2012 r. rozpoczęła się również budowa nowego terminalu w Dunkierce u wybrzeży Francji, który ma posiadać największe zdolności przeładunkowe spośród wszystkich tego typu instalacji w Europie kontynentalnej. Wyposażony będzie także w trzy zbiorniki magazynowe, każdy o pojemności 190 tys. $\mathrm{m}^{3160}$. W rozbudowie znajduje się także ogromna instalacja w porcie Zeebrugge w Belgii, jak również terminal $\mathrm{w}$ greckim Revithoussa ${ }^{161}$. Prowadzone są również prace nad powiększeniem podziemnego magazynu gazu w Inčukalns na Łotwie, będącego jak na razie jedynym magazynem gazu w regionie bałtyckim ${ }^{162}$ o pojemności $2,3 \mathrm{mld} \mathrm{m}^{3}$ (planowana rozbudowa finalnie do 3,2 $\mathrm{mld} \mathrm{m}^{3163}$ ). Większość $\mathrm{z}$ wymienionych inwestycji stanowią projekty wspólnego zainteresowania (PCI), wobec czego przysługuje im dodatkowe finansowanie z budżetu unijnego, jak również ułatwienia na drodze postępowań administracyjnych.

Zwiększenie liczby terminali przeznaczonych do odbioru surowca nie przedstawia jedynie korzyści w postaci możliwości importowania większej ilości gazu. Rozbudowana infrastruktura importowa umożliwi bardziej efektywne wykorzystanie istniejących już obecnie w Europie zdolności magazynowania gazu ${ }^{164}$, które są wykorzystywane jedynie w ok. 30\%, o czym będzie mowa w dalszej części pracy.

Nie można pominąć faktu, że istotnym utrudnieniem dla powstania płynnego rynku LNG w UE jest obecnie niewystarczająca liczba połączeń międzysystemowych na terenie Unii. Szczególnie zachodnia Europa, na skutek dostępu do surowca sprowadzanego nie tylko z Rosji, ale również z północnej Afryki, Morza Północnego i Norwegii, posiada słabiej rozwiniętą sieć połączeń, jak również mniejsze zdolności magazynowe ${ }^{165}$. Kluczową kwestią jest rozbudowa połączeń na liniach: Hiszpania Francja, Francja - Niemcy, Francja - Włochy, Wielka Brytania - Francja. Jeszcze pilniejszą sprawą zdaje się usunięcie deficytu infrastruktury przesyłowej na terenie Europy Środkowo-Wschodniej oraz na Bałkanach. Jest to warunek konieczny dla powstania jednego europejskiego rynku gazu ziemnego.

W tym miejscu należy więc wymienić także projekty połączeń międzysystemowych mające na celu zwiększenia przepływów surowca między poszczególnymi państwami. Należą do nich ${ }^{166}$ :

159 About Us, LNG Hrvatska, [online] http://www.lng.hr/en/about-us, 25 III 2016.

160 A. Grobarčíková, J. Sosedová, T. Kalina, Development of LNG Infrastructure..., s. 37.

161 Tamże.

162 Consultation on an EU strategy for liquefied natural gas..., s. 3.

163 Description of the storage facility, Latvijas Gaze, [online] http://www.lg.lv/?id=194\&lang=eng, 19 V 2016.

164 M. Ruszel, Polityczne znaczenie ...

165 Consultation on an EU strategy for liquefied natural gas..., s. 10.

166 Commission Staff working document..., s. 21. 
- gazociąg GIPL łączący Polskę i Litwę (planowana przepustowość z Polski do Litwy: $2,4 \mathrm{mld} \mathrm{m}^{3}$, zaś z Litwy do Polski: $1,7 \mathrm{mld} \mathrm{m}^{3}$, planowana data oddania do użytku: 2019) ${ }^{167}$, którego celem jest pełne zintegrowanie systemu gazowego państw bałtyckich z zachodnią Europą;

- gazociąg Bułgaria - Serbia (tzw. IBS, planowana przepustowość: 1,8 $\mathrm{mld} \mathrm{m}^{3}$, data studium wykonalności: 2018$)^{168}$;

- gazociąg Grecja - Bułgaria (tzw. IGB, planowana przepustowość: ok 13,7 mln $\mathrm{m}^{3}$ dziennie - ok. $5 \mathrm{mld} \mathrm{m}^{3}$ rocznie $)^{169}$;

- wdrożenie rewersu na połączeniu Bułgaria - Rumunia;

- projekt MidCat (interkonektor łączący Hiszpanię i Francję);

- trzeci interkonektor łączący Hiszpanię i Portugalię;

- zwiększenie przepustowości gazociągu Estonia - Łotwa (planowana przepustowość: $10 \mathrm{mln} \mathrm{m}^{3}$ dziennie, czyli ok. $3,56 \mathrm{mld} \mathrm{m}^{3}$ rocznie, planowane oddanie do użytku: 2019) ${ }^{170}$.

Komisja Europejska już na etapie konsultacji unijnej strategii LNG zauważała zagrożenia stojące na drodze do rozwoju strategicznej infrastruktury. Zwracała przede wszystkim uwagę na olbrzymią kapitałochłonność inwestycji, która częstokroć prowadzi do wieloletnich opóźnień w oddaniu obiektów do użytkowania. Wiele projektów napotyka problemy natury prawnej, w postaci różnorakich barier administracyjnych. Niejednokrotnie hamulcem w rozwoju staje się także brak społecznej akceptacji dla tworzenia instalacji przynoszących uszczerbek krajobrazowi czy naruszających swobodę gospodarowania na terenach przeznaczonych pod inwestycje. Nieraz problemem jest znalezienie środków finansowych na budowę terminali czy infrastruktury magazynowej pomimo unijnego wsparcia. Co ważne, częstokroć argumentem zniechęcającym do budowy infrastruktury o konkretnym przeznaczeniu (np. regazyfikacyjnej - importowej) jest brak komplementarnych instalacji umożliwiających jej efektywne wykorzystanie (np. magazynów gazu) ${ }^{171}$.

Wymienione projekty stanowią kluczowe wyzwania dla państw Unii, które muszą być brane pod uwagę przy wdrażaniu strategii dla LNG, jak również przy tworzeniu tzw. unii energetycznej. O ile, zdaniem autora, kwestie niewłaściwych regulacji administracyjnoprawnych powinny być rozwiązane na gruncie systemów państw członkowskich, bez zbędnej dodatkowej regulacji unijnej, o tyle już aktywna realizacja przyjętej ogólnoeuropejskiej strategii, zakładającej tworzenie komplementarnych projektów infrastrukturalnych, odpowiednio rozłożonych na powierzchni kontynentu, winna stanowić priorytetową płaszczyznę zainteresowania UE. Regularne dostawy LNG za pomocą rozbudowanej infrastruktury stworzą mechanizmy alokacji gazu na światowych i regionalnych rynkach w zależności od istniejącego zapotrzebowania. W sytuacji cie-

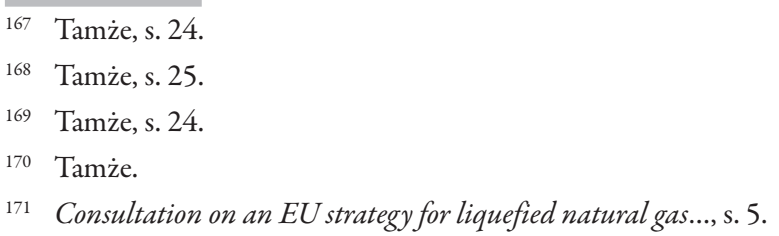


płej zimy w Europie nadpodaż LNG zostanie przerzucona i skonsumowana przez państwa azjatyckie ${ }^{172}$. Oczywiście będzie to miało pozytywny wpływ na konkurencyjność dostaw. Z punktu widzenia bezpieczeństwa Polski zaś kluczowe znaczenie ma otwarcie terminalu na wyspie Krk w Chorwacji oraz zwiększenie przepustowości połączenia gazowego z Czechami. Wskazane inwestycje umożliwią przesył gazu pomiędzy państwami Grupy Wyszehradzkiej i Chorwacją, a w przyszłości również państwami bałtyckimi ${ }^{173}$.

\section{KRÓTKOTERMINOWE PROGNOZY DLA RYNKU LNG}

\subsection{Kilkuletnie ograniczenie inwestycji}

Nie brakuje zjawisk o charakterze makroekonomicznym, które mogą budzić uzasadnione obawy o rozwój handlu LNG. Rok 2014, charakteryzujący się stosunkowo łagodną zimą w Europie, odbił się negatywnie na stopniu wykorzystania gazu. Należy się jednak spodziewać, że na skutek wzmożonego zużycia LNG do produkcji energii elektrycznej zapotrzebowanie na gaz w UE wzrośnie do 2020 r. o jedną trzecią. IEA prognozuje utrzymanie obecnego importu gazu droga gazociągową z Rosji na obecnym poziomie (150-160 $\left.\mathrm{mld} \mathrm{m}^{3}\right)$ i jednoczesne podwojenie importu LNG ${ }^{174}$.

Bardziej niepokojącym zjawiskiem jest spowolnienie chińskiej gospodarki. Spadek popytu na surowce w Państwie Środka wpłyną już istotnie na ceny ropy i gazu. Trzeba zaznaczyć jednak, że wzrost gospodarczy Chin na poziomie 7\% wciąż pozostaje imponujący. Analitycy IEA nie wykluczają, że mimo mniejszej konsumpcji energii import gazu zostanie zachowany. Dlaczego miałoby do tego dojść? Otóż może być podobnie jak w przypadku wzrostu importu w UE. Chiny, które ostrożnie godzą się na kolejne systemowe działania w kierunku polityki ochrony środowiska przyrodniczego, mogą stopniowo rezygnować ze stosowania węgla na korzyść gazu, projektując elektrownie działające w oparciu o ten surowiec ${ }^{175}$.

Większe zapotrzebowanie nagazzgłaszają również państwa Ameryki Południowej ${ }^{176}$. O gotowości uruchomienia eksportu informują kolejni światowi gracze, m.in. z Afryki ${ }^{177}$. Swój udział w rynku LNG chce zaznaczyć również Federacja Rosyjska, która obecnie za pomocą terminala eksportowego na wyspie Sachalin sprzedaje surowiec

\footnotetext{
172 M. Ruszel, Polityczne znaczenie...

173 W 2019 r. planowane jest oddanie do użytku wspomnianego połączenia gazowego pomiędzy Litwą a Polską, które umożliwi przesył pierwotnie ok. 2,4 $\mathrm{mld} \mathrm{m}^{3} \mathrm{w}$ stronę litewską oraz ok. 1,7 $\mathrm{mld} \mathrm{m}^{3}$ w stronę polską.

174 Gas-medium-term market report 2015..., s. 6.

175 Tamże, s. 4.

176 Tamże.

177 D. Malinowski, Gazprom kupi LNG w Kamerunie, Portal Gospodarczy Nowy Przemysł, 30 XI 2015, [online] http://gazownictwo.wnp.pl/gazprom-kupi-lng-w-kamerunie,262400_1_0_0.html, 25 III 2016.
} 
przeznaczony na rynki azjatyckie ${ }^{178}$. Nie można zapominać również o gwałtownie rosnącym potencjale Indii. Państwo to w 2015 r. konsumowało ok. $23 \mathrm{mld} \mathrm{m}^{3}$, co wobec znaczącej liczby ludności jest wielkością niewielką. W ciągu sześciu lat zużycie gazu ma jednak wzrosnąć do ponad $110 \mathrm{mld} \mathrm{m}^{3}$, w dużej mierze dzięki zwiększonemu importowi $\mathrm{LNG}^{179}$. IEA prognozuje więc utrzymanie się trendu wzrostowego na rynku LNG do $2020 \mathrm{r}^{180}$

Pewne zjawiska są jednak nieuchronne. W obliczu drastycznie niskich cen ropy spadają ceny gazu. Niezależnie od przyjętej formuły cenowej są one bowiem nierozerwalnie powiązane ze sobą. Kapitałochłonne inwestycje związane z budową infrastruktury dla LNG nie przedstawiają więc obecnie optymalnej perspektywy zwrotu kapitału. Zdaniem IEA można się spodziewać, że znajdujące się obecnie w trakcie budowy projekty LNG zostaną ukończone, natomiast kolejne inwestycje w najbliższych latach prawdopodobnie się nie pojawią ${ }^{181}$. Wiele projektów inwestycyjnych zostało uruchomionych jeszcze przed dekoniunkturą na rynkach ropy i gazu, a obecnie ich poziom zaawansowania nie pozwala na ich porzucenie ${ }^{182}$. Oznacza to, że zdolności przeładunkowe zwiększą się o 40\% w skali globu do końca bieżącej dekady. Jak już zostało powiedziane, dalszy spadek cen nie powinien skutkować spadkiem obrotów handlowych gazem LNG. Wręcz przeciwnie: można spodziewać się agresywnej gry rynkowej, polegającej na stałym zwiększaniu podaży LNG, podobnie jak dzieje się na rynku ropy. Wzmożony eksport gazu skroplonego będzie trwał dopóty, dopóki cena za surowiec będzie pokrywała koszty operacyjne oraz koszty transportu ${ }^{183}$. Jeżeli planowane inwestycje zostaną zrealizowane, do 2018 r. w UE przybędzie kolejne $35 \mathrm{mld} \mathrm{m}^{3}$ zdolności regazyfikacyjnych ${ }^{184}$.

UE, w sytuacji obecnej nadwyżki podaży na rynku, ma możliwość nabywania gazu od zupełnie nowych dostawców i zaprzepaszczenie tej szansy byłoby niekorzystne. Szczególnie obiecującymi kierunkami są USA oraz Australia, Oman, Jemen czy rozwijające swe zdolności eksportowe państwa wschodniej Afryki. W każdym wypadku czynnikiem decydującym będzie cena oraz warunki umowy. Pożądanym zjawiskiem byłoby jednak zawieranie wielu kontraktów i maksymalne zróżnicowanie kierunków dostaw.

\footnotetext{
J. Deutch, The good news about gas..., s. 91.

179 W. Krzyczkowski, LNG w 2016: nowa podaż, dodatkowi odbiorcy, Wysokie Napięcie, 25 I 2016, [online] http://wysokienapiecie.pl/gaz-ziemny/1244-lng-w-2016-dodatkowa-podaz-nowi-odbiorcy, 25 III 2016.

180 Gas-medium-term market report 2015..., s. 4.

182 R. Zajdler, $L N G$ tańsze o potowę.

183 Tamże, s. 5.

184 M. Ruszel, Polityczne znaczenie...
}

181 Tamże. 


\subsection{Boom łupkowy w USA oraz eksport z Australii i Kanady}

Spodziewane światowe dostawy LNG w 2018 r. mają osiągnąć wartość $330 \mathrm{mln}$ ton $^{185}$, tj. ok. $449 \mathrm{mld} \mathrm{m}^{3}$ (przy obecnych ok. $245 \mathrm{mln}$ ton $^{186}$ ). Spowodowane to będzie m.in. rosnącym eksportem z USA oraz Australii, które mają potencjał, aby doścignąć największego gracza na rynku LNG - Katar. Ostatnie lata pokazują, że zdolności eksportowe naftowego mocarstwa pozostają na tym samym poziomie, podczas gdy inni dostawcy wciąż budują nową infrastrukturę eksportową. W 2014 r. państwo szejków przetransportowało 77,8 $\mathrm{mln}$ ton LNG (ok. $106 \mathrm{mld} \mathrm{m}^{3}$ gazu), co zapewniło mu udział w rynku na poziomie ok. $32 \%{ }^{187}$. Nie powinno to dziwić wobec faktu, ze Katar dysponuje całym łańcuchem handlowym dostaw, począwszy od produkcji, poprzez przetwarzanie do postaci skroplonej, na dostawie do odbiorcy kończąc. Pozostaje również największym dostawcą na rynku spotowym. Koszty produkcji gazu w Katarze są również kilkukrotnie niższe od tych w USA czy Australii. Umożliwia to państwu elastyczne przerzucanie ścieżek dostaw i znajdowanie nabywców dla swojego produktu $^{188}$.

$\mathrm{Na}$ podstawie pojawiających się prognoz można stwierdzić, że aż 55\% (ok. $32 \mathrm{mln}$ ton) produkcji LNG w USA trafi w 2020 r. na rynek europejski ${ }^{189}$. Co ciekawe, przedsiębiorstwo Cheniere Energy jeszcze 10 lat temu budowało u wybrzeży Luizjany terminal Sabine Pass z intencją importu LNG wobec prognozowanych braków surowca. Później, po nastaniu rewolucji łupkowej, ta sama instalacja dostosowana została do eksportu surowca ${ }^{190}$. USA czerpią ogromne profity z wykorzystania technologii poziomych odwiertów oraz tzw. szczelinowania hydraulicznego formacji łupkowych bogatych w ropę oraz gaz ${ }^{191}$. Amerykanie zdają sobie sprawę z tego, że bezpieczeństwo energetyczne w Europie w świetle powszechnie obowiązującego paradygmatu oznacza przede wszystkim konieczność dywersyfikacji źródeł importu surowców, jak również dostawców, i chcą na tej doktrynie zarobici ${ }^{192}$. Nie podjęto jednak decyzji o przeprowadzeniu większości z planowanych inwestycji, mimo iż w 2015 r. Departament Energii USA zezwolił na zwiększenie eksportu LNG do państw, które nie mają z USA umowy o wolnym handlu (w tym do UE). Jedyną istotną instalacją pozostaje wspomniany

185 M. Sergie, Biggest no longer means best in Qatar's strategy for LNG wealth, Bloomberg, 6 I 2016, [online] http://www.bloomberg.com/news/articles/2016-01-06/biggest-no-longer-means-best-in-qatar-s-strategy-for-lng-wealth, 25 III 2016.

186 Obliczenia własne na podstawie: BP Statistical Review..., s. 29.

1872016 World LNG Report, s. 7.

188 M. Sergie, Biggest no longer means best...

189 A. Shiryaevskaya, More than half of U.S. LNG is destined for Europe...

190 T. Loh, C. Buurma, H. Weber, American LNG exporters...

191 J. Carroll, N. Malik, Shale hoard behind U.S. energy renaissance set loose on globe, Bloomberg, 4 I 2016, [online] http://www.bloomberg.com/news/articles/2016-01-04/shale-hoard-behind-u-s-energy-renaissance-set-loose-on-globe, 25 III 2016.

192 T. Loh, C. Buurma, H. Weber, American LNG exporters... 
Sabine Pass o zdolności eksportowej na poziomie $24,5 \mathrm{mld} \mathrm{m}^{3}{ }^{193}$. Wciąż nie doszło do pełnego uwolnienia eksportu gazu, podobnie jak to stało się w grudniu 2015 r. w odniesieniu do ropy naftowej. $Z$ zakazu funkcjonującego w USA od $1938 \mathrm{r}$. administracja zwalania w drodze indywidualnych decyzji ${ }^{194}$. Procedura ta wciąż jest czasochłonna i droga ${ }^{195}$. Koncepcja eksportu LNG znajduje również przeciwników wewnątrz kraju. Lobby przemysłowe, reprezentujące interesy producentów stali oraz aluminium, postuluje przeznaczenie nadwyżki surowca jedynie na potrzeby rynku wewnętrznego ${ }^{196}$. Zwraca się uwagę również na brak przygotowania UE do importu tak znacznych ilości surowca $z$ uwagi na niewystarczające zdolności regazyfikacyjne ${ }^{197}$.

W 2020 r. Stany Zjednoczone osiągną zdolność do eksportu ponad $60 \mathrm{mln}$ ton $\left(83 \mathrm{mld} \mathrm{m}^{3}\right)$ LNG rocznie. W najbliższym czasie planowane jest oddanie do użytku kolejnych terminali. Trwają prace nad pięcioma instalacjami: Sabine Pass, Corpus Christi, Freeport LNG (Teksas), Cameron LNG (Luizjana), Cove Point LNG (Maryland) ${ }^{198}$.

Światowy eksport może wzrosnąć nie tylko dzięki nadwyżkom z USA, ale również planowanej sprzedaży z Australiii ${ }^{199}$. W tym drugim państwie w budowie są obecnie projekty inwestycyjne, które zwiększą zdolności eksportowe państwa o $90,5 \mathrm{mld} \mathrm{m}^{3}$ (z czego największy terminal Gorgon LNG będzie odpowiadał za niemalże $\left.21,5 \mathrm{mld} \mathrm{m}^{3}\right)^{200}$. Zaznaczyć należy, że w latach 2007-2014 produkcja LNG w Australii wzrosła o ponad połowę, do $31 \mathrm{mld} \mathrm{m}^{3201}$. Australijczycy mierzą się jednak obecnie z problemem wyjątkowo wysokich kosztów związanych z wymienionymi inwestycjami ${ }^{202}$. Na analogiczny problem natrafiają USA, gdyż aby inwestycje w moce eksportowe LNG były biznesowo opłacalne, wymagana jest cena baryłki ropy naftowej na poziomie minimum 60 dolarów za baryłkę, podczas gdy przy cenie 50 dolarów za baryłkę dochodzi jedynie do pokrycia kosztów ${ }^{203}$.

Nadpodaż na innych rynkach może mieć istotne znaczenie z punktu widzenia Starego Kontynentu, gdyż nie brak głosów, że w ciągu najbliższych lat wysoka cena LNG nabywanego w USA i transportowanego do Europy sprawi, że amerykański LNG nie będzie na tyle konkurencyjny, aby dostawy przez Atlantyk stanowiły istotny wo-

193 M. Gałczyński i in., Globalny rynek LNG, s. 125-126.

194 P. De Micco, Could US oil and gas exports be a game changer for EU energy security?, European Parliament, Directorate-General for Energy Policies, II 2016, s. 3, [online] http://www.europarl.europa.eu/RegData/etudes/IDAN/2016/570462/EXPO_IDA(2016)570462_EN.pdf, 23 IV 2016.

195 Tamże, s. 7.

196 Tamże, s. 10

197 Tamże.

198 E. Crooks, Cheniere's Energy shipment turns US into gas exporter, „Financial Times” 2016, 10 I, [online] http://www.ft.com/intl/cms/s/0/f1773832-b5ee-11e5-b147-e5e5bba42e51.html\#axzz46doQACm2, 23 IV 2016.

199 A. Shiryaevskaya, More than half of U.S. LNG is destined for Europe...

200 M. Gałczyński i in., Globalny rynek LNG, s. 113.

201 Tamże, s. 134.

202 Tamże, s. 102.

203 P. De Micco, Could US oil and gas exports..., s. 8. 
lumen importowanego do Unii gazu ${ }^{204}$. Uzasadnione jest również pytanie o intencje USA. Wydaje się, że naczelnym celem jest utrzymanie niskich cen surowca na rynku krajowym, co pozwoli zatrzymać odpływ amerykańskich inwestycji do Chin oraz przywrócić koniunkturę dla przemysłu na terenie kraju. $Z$ tej przyczyny za granicę trafi ograniczona ilość amerykańskiego LNG, tak aby ceny wewnętrzne ani nie spadły poniżej progu opłacalności wydobycia, ani nie wzrosły wskutek zbyt niskiej podaży na rynku krajowym $^{205}$. Zgodnie z obliczeniami IEA ceny gazu sprowadzanego z USA dla państw UE kształtować się będą w przedziale 320-430 USD/mld $\mathrm{m}^{3}$. Przy obecnych uwarunkowaniach rynkowych nie jest to cena atrakcyjna. Dodatkowo, w związku z przewidywaniami, iż ceny na rynku azjatyckim będą ok. $25 \%$ wyższe niż w Europie, trafi tu prawdopodobnie jedynie surowiec, którego nie uda się sprzedać na Wschodzie ${ }^{206}$.

Innym kierunkiem potencjalnych dostaw, o którym warto wspomnieć, jest Kanada. Państwo posiadające udokumentowane zasoby gazu na poziomie $2 \mathrm{bln}^{3}$, a więc przewyższające zasoby Norwegii czy Kuwejtu ${ }^{207}$, ma daleko idące plany eksportu surowca wydobywanego w zachodniej części kraju, w Kolumbii Brytyjskiejej ${ }^{208}$. Pomimo iż Krajowa Rada Energii (National Energy Council - NEC) wydała już 23 licencje na eksport surowca, żaden komercyjny projekt nie został zapoczątkowany ${ }^{209}$. Zauważyć jednak należy, że dopiero pod koniec 2014 r. doszło do wdrożenia ustawy podatkowej dla projektów LNG, stanowiącej krok naprzód w kierunku liberalizacji systemu ${ }^{210}$. Trudno na chwilę obecną ocenić, jak wysoki może być poziom LNG transportowanego z Kanady do Europy. Nic nie wskazuje na to, żeby planowane projekty mogły zostać zrealizowane przed końcem obecnej dekady, stąd kanadyjski LNG, w warunkach narastającej podaży na światowych rynkach, może mieć problem z odnalezieniem zapotrzebowania po stronie popytowej. Dodatkowo, bliższym kierunkiem dostaw z Kolumbii Brytyjskiej jest konsumująca wciąż znaczne ilości gazu Azja ${ }^{211}$.

\section{UNIJNA STRATEGIA DLA LNG ORAZ MAGAZYNOWANIA}

Dnia 16 lutego 2016 r. opublikowany został tzw. pakiet zimowy UE, a więc zbiór dokumentów poświęconych problematyce bezpieczeństwa gazowego państw członkowskich. Pakiet obejmuje m.in. nowelizację dwóch aktów prawa wtórnego, tj. roz-

\footnotetext{
204 Impact of US LNG exports on Europe - White Paper, s. 4.

205 M. Gałczyński i in., Globalny rynek LNG, s. 125.

206 Tamże, s. 127.

207 BP statistical review..., s. 20.

208 Canada's Energy Future 2016. Energy supply and demand projections to 2040, Her Majesty the Queen in Right of Canada as represented by the National Energy Board 2016, s. 101, [online] https://www. neb-one.gc.ca/nrg/ntgrtd/ftr/2016/2016nrgftr-eng.pdf, 23 IV 2016.

209 Tamże.

210 World LNG Report - 2015 edition, s. 31.

211 Canada's Energy Future..., s. 102.
} 
porządzenia 994/2010 w sprawie środków zapewniających bezpieczeństwo dostaw gazu ziemnego (tzw. rozporządzenia SoS) oraz decyzji 994/2012 w sprawie ustanowienia mechanizmu wymiany informacji $w$ odniesieniu do umów międzyrządowych $w$ dziedzinie energii między państwami cztonkowskimi a państwami trzecimi (tzw. decyzja IGA - Inter-Governmental Agreements), a także strategię dotyczącą chłodnictwa i cieplownictwa ${ }^{212}$.

W ramach pakietu znalazła się również strategia dla LNG oraz magazynowania gazu. Nie przyniosła wielu zaskoczeń. Jej autorzy podkreślili, że w celu uczynienia rynku LNG atrakcyjnym dla potencjalnych importerów konieczne jest spełnienie trzech warunków ${ }^{213}$ :

- zapewnienie odpowiedniego dostępu do infrastruktury, tak aby każde państwo unijne mogło czerpać korzyści z dostępu do międzynarodowego rynku LNG;

- ukończenie procesu powstawania wewnętrznego rynku gazu, co pozwoliłoby na właściwą alokację przepływu surowca oraz bodźców do budowy nowej infrastrutury tam, gdzie jest to niezbędne;

- usuwanie barier dla rozwoju rynku LNG poprzez prowadzenie dialogu z obecnymi i przyszłymi dostawcami, jak również największymi odbiorcami surowca.

Odnośnie do aspektu infrastrukturalnego Komisja podkreśla, że obecnie istniejące terminale regazyfikacyjne w UE zapewniają wysoki poziom mocy importowych, jednakże nie gwarantują równomiernej dystrybucji do wszystkich potrzebujących państw członkowskich. Zjawiskiem obserwowanym w ostatnich latach jest również stosunkowo niski poziom wykorzystywania mocy terminali z uwagi na wyższe ceny LNG na rynku azjatyckim, które przyciągają kierowanych chęcią zysku dostawców ${ }^{214}$. Należy zgodzić się ze stanowiskiem komisarzy, iż problemu nie stanowi sam poziom zdolności regazyfikacyjnych terminali. W 2015 r. wyniosły one $195 \mathrm{mld} \mathrm{m}^{3}$ (nie wliczając w to zdolności terminalu w Świnoujściu). Dzięki budowanym inwestycjom w 2019 r. poziom ten wzrośnie do ponad $200 \mathrm{mld} \mathrm{m}^{3215}$. Są to wartości stosunkowo wysokie, biorąc pod uwagę unijną konsumpcję wynoszącą w ostatnich latach ok. 400-450 mld $\mathrm{m}^{3}$. Negatywnym zjawiskiem jest za to niedostateczna liczba połączeń międzysystemowych, co uniemożliwia w pełni swobodny przepływ surowca na terenie wspólnoty. Podobnie, uwagę zwraca nierównomierne rozmieszczenie terminali regazyfikacyjnych. Wciąż widoczne są zaniedbania pod tym względem w regionie bałtyckim, Europie Środkowo-Wschodniej, na Bałkanach i Półwyspie Apenińskim.

Komisja pozytywnie oceniła również zdolności magazynowe państw członkowskich, uznając je za wystarczające. Zwróciła jednakże uwagę na konieczność wdrożenia ułatwień infrastrukturalnych oraz regulacyjnych dla umożliwienia międzysystemo-

\footnotetext{
212 Gazowy pakiet bezpieczeństwa dostaw a rynek UE, Ministerstwo Energii, 9 II 2016, [online] http:// www.mg.gov.pl/node/25796, 25 III 2016.

213 Communication from the Commission..., s. 2-3.

214 Tamże, s. 4.

215 Commission Staff working document..., s. 12.
} 
wego wykorzystania tychże zdolności ${ }^{216}$. Odnosząc się do argumentu przestawionego przez Komisję, zauważyć należy, że zdolności magazynowe państw UE wynoszą obecnie $93 \mathrm{mld} \mathrm{m}^{3}$. Dodatkowo, magazyny na terenie Ukrainy szacowane są na $31 \mathrm{mld} \mathrm{m}^{3217}$. Zdolności magazynowe pokrywają więc ok. $20-25 \%$ poziomu zapotrzebowania na terenie Unii. Przyjęty dosyć powszechnie pogląd pozwala uznać, że o odpowiednim poziomie rezerw można mówić w sytuacji, gdy dane państwo ma zdolności magazynowania co najmniej 20-30\% swego całkowitego zapotrzebowania na surowiec. Wskazać więc należy, że istotnie zdolności magazynowe osiągnęły już dosyć wysoki poziom. Podobnie jednak jak w odniesieniu do zdolności regazyfikacyjnych, które są rozwinięte na stosunkowo wysokim poziomie, wskazać należy, że konieczne jest zwiększenie połączeń międzysystemowych, tak aby infrastruktura magazynowa była wykorzystywana w sposób bardziej efektywny i aby korzyści z ich istnienia odnosiła Unia jako całość. Ponadto zdolności magazynowe, podobnie jak regazyfikacyjne, powinny być bardziej równomiernie rozmieszczone na terenie państw członkowskich. Obecnie stosunkowo wysoki poziom wykazują w tym aspekcie takie państwa, jak Włochy, Niemcy, Francja czy Holandia. Państwa Europy Środkowo-Wschodniej, jak również państwa bałkańskie cechują się znacznie niższymi zdolnościami magazynowymi na terenie swych państw, jednakże równocześnie znacznie mniej konsumują, stąd zdolności magazynowe obliczone są na ich potrzeby (ryc. 3). Jedynie Polska przedstawia niski wskaźnik zdolności magazynowych. Z kolei dla państw bałtyckich jedynym magazynem jest wspomniany system podziemnych magazynów w Inčukalns na Łotwie, choć warto dodać, że ich potrzeby nie są bardzo wysokie i w dodatku się zmniejszają. Zdolności magazynowych w ogóle nie ma za to Grecja ${ }^{218}$. Między innymi dla takich państw istotna jest rozbudowana infrastruktura przesyłowa, tak aby możliwy był import gazu od lepiej zaopatrzonego sąsiada.

Dla wyjaśnienia dodać należy, że opisywane instalacje nie są tożsame z infrastrukturą magazynową LNG, a więc magazynów funkcjonujących bezpośrednio przy terminalach regazyfikacyjnych. Ich zdolności w ramach UE wynoszą $4,8 \mathrm{mld} \mathrm{m}^{3219}$, a ich rola polega na zapewnieniu właściwego funkcjonowania terminalu, $w$ tym bezpiecznego procesu regazyfikacji ${ }^{220}$.

Unia zdaje się w strategii przykładać większą wagę do projektów interkonektorów. Gdy chodzi o najpilniejsze projekty LNG, KE wskazuje, że jej szczególnym zainteresowaniem będą cieszyć się projekty zaproponowane przez grupę wysokiego szczebla ds. połączeń gazowych w Europie Środkowej i Południowo-Wschodniej (Central East South Europe Gas Connectivity Group - CESEC), regionalny plan inwestycyjny na

216 Communication from the Commission..., s. 5.

217 EU Storage Data for Tuesday 24-03-2016, Gas Infrastructure Europe, [online] http://transparency.gie. $\mathrm{eu} /, 25$ III 2016.

218 Commission Staff working document..., s. 15.

219 Same tylko Hiszpania i Wielka Brytania odpowiadają za ok. 65\% tych zdolności. M. Gałczyński i in., Globalny rynek $L N G$, s. 46.

220 M. Gałczyński i in., Globalny rynek LNG, s. 46-47. 
obszarze bałtyckim (Baltic Energy Market Interconnection Plan - BEMIP) oraz państwa obszaru Europy Południowo-Zachodniej (SWE) ${ }^{221}$, które to inwestycje zostały wymienione w rozdziale 3.4. Czynnikiem ograniczającym inwestycje jest ich kapitałochłonność, stąd proponowane jest skorzystanie z możliwości kredytowania, w tym z usług Europejskiego Funduszu Inwestycji Strategicznych, Europejskiego Funduszu Rozwoju Regionalnego czy programu „Łącząc Europę” (CEF) ${ }^{222}$.

Ryc. 3. Zdolności magazynowe poszczególnych państw członkowskich UE na tle rocznego zapotrzebowania na gaz ziemny

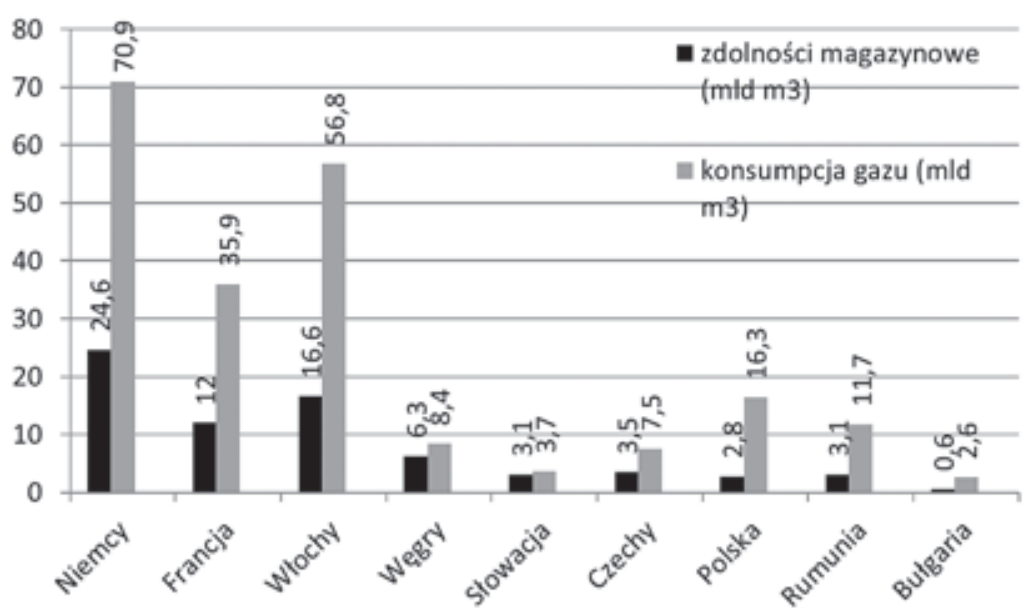

Źródło: opracowanie własne na podstawie BP Statistical Review of World Energy, VI 2015, s. 23, [online] https://www.bp.com/content/dam/bp/pdf/energy-economics/statistical-review-2015/bp-statistical-review-of-world-energy-2015-full-report.pdf, 25 III 2016 oraz Commission Staff working document accompanying the document: Communication from the Commission to the European Parliament, the Council, the European Economic and Social Committee and the Committee of the Regions on an EU strategy for liquefied natural gas and gas storage, European Commission, Brussels, 16 II 2016, s. 15, [online] http://eur-lex. europa.eu/legal-content/EN/TXT/PDF/?uri=CELEX:52016SC0023\&from=pl, 25 III 2016.

Drugim wyzwaniem, na które zwraca uwagę Komisja, jest pełna realizacja procesów liberalizacyjnych na rynkach gazu. Komisja zauważa, że wciąż wiele projektów LNG korzysta z możliwości wyłączenia spod reżimu trzeciego pakietu energetycznego, jako tzw. nowa infrastruktura ${ }^{223}$. Nieobjęte obowiązkiem udostępniania fizycznego rewersu, czyli wolnego przepływu surowca w obie strony, są połączenia gazowe na linii:

221 Communication from the Commission..., s. 6.

222 Tamże, s. 7.

223 Art. 36 dyrektywy Parlamentu Europejskiego i Rady nr 2009/73 dotyczącej wspólnych zasad wewnętrznego rynku gazu ziemnego wskazuje, że istotna nowa infrastruktura gazowa nieukończona przed 4 VIII 2003 r. może na wniosek zostać zwolniona ze stosowania niektórych przepisów dyrektywy, $\mathrm{w}$ tym mówiących o rozdziale prawnym operatora systemu przesyłowego $\mathrm{w}$ przedsiębiorstwie zintegrowanym pionowo czy zasady dostępu stron trzecich do infrastruktury gazowej (Third Party Access - TPA). 
Francja - Niemcy, Niemcy - Czechy, Wielka Brytania - Holandia ${ }^{224}$. Sześć instalacji LNG w Unii pozostaje zaś zwolnione z obowiązku respektowania zasady TPA, tj. z odpłatnego choćby udostępniania swojej infrastruktury podmiotom trzecim ${ }^{225}$. Oznacza to, że możliwość korzystania z terminalu nie jest otwarta dla wszystkich, a warunki są ustalane w takim przypadku zawsze w oparciu o indywidualne uzgodnienia pomiędzy właścicielem infrastruktury a podmiotami pragnącymi z niej skorzystać. Wobec tego zaleca się krajowym organom regulacyjnym przyjęcie planów mających na celu określenie środków niezbędnych dla pełnego objęcia wszystkich inwestycji regulacjami prawa europejskiego, zwłaszcza w regionie BEMIP. Jednocześnie postuluje się ukończenie prac nad włączeniem Półwyspu Iberyjskiego do rynku gazu ${ }^{226}$, dzięki wykonaniu fizycznych przyłączeń.

Dokument zwraca uwagę na istotne problemy praktyczne, z jakimi spotykają się podmioty handlujące LNG. Są one związane z wykorzystywaniem krajowych zdolności magazynowych. Częstokroć podmiot gospodarczy, który chce zatłoczyć określoną ilość gazu do magazynu w danym państwie członkowskim, musi płacić podwójne opłaty taryfowe: po raz pierwszy za zatłoczenie, a po raz drugi za odbiór z magazynu ${ }^{227}$. Dodatkowo wciąż niezbędne jest stworzenie mechanizmów właściwej alokacji surowca na poszczególnych krajowych rynkach. Żeby zrealizować powyższe cele, konieczne jest nie tylko wdrożenie instrumentów prawnych w postaci kodeksów sieci, ale również pogłębienie międzypaństwowej współpracy celem optymalizacji wykorzystania zdolności magazynowych 228 .

Proponowanym rozwiązaniem jest racjonalizacja wykorzystania zdolności magazynowych poprzez tworzenie planów regionalnych, zgodnie z opracowywaną nową dyrektywą $S o S^{229}$. Dokumenty te powinny regulować m.in. kwestie nierynkowych środków ukierunkowanych na efektywniejsze wykorzystanie zdolności magazynowych, a więc np. istniejących już obecnie mechanizmów zapasów obowiązkowych oraz rezerwy strategicznej $j^{230}$.

Wobec projektu nowej decyzji IGA Komisja dokona sprawdzenia zawartych umów międzyrządowych, także tych dotyczących LNG, pod kątem ich zgodności z prawem $\mathrm{UE}^{231}$.

Komisja postuluje otwarcie się na nowych dostawców LNG. Dokument wymienia Katar, Nigerię, Egipt, Angolę, Mozambik, Tanzanię, Izrael, Liban, Iran, Irak i Libię jako

\footnotetext{
224 A. Gawlikowska-Fyk, W. Gruszczyński, Z. Nowak, Pakiet gazowy: kolejny etap starań o wzmocnienie odporności energetycznej UE, Biuletyn Polskiego Instytutu Spraw Międzynarodowych, nr 9 (1359), 3 II 2016, s. 2, [online] https://www.pism.pl/files/?id_plik=21337, 25 III 2016.

225 Commission Staff working document..., s. 13.

226 Communication from the Commission..., s. 8.

227 Tamże, s. 9.

228 Tamże, s. 9-10.

229 Tamże, s. 10.

230 Commission Staff working document..., s. 20.

231 Communication from the Commission..., s. 11.
} 
potencjalnych dostawców surowca. Wskazana jest również konieczność prowadzenia dialogu z największymi konsumentami gazu skroplonego (Japonią, Koreą Południową, Chinami i Indiami) celem osiągnięcia wspólnie zakładanych celów w postaci transparentnego i płynnego rynku $\mathrm{LNG}^{232}$.

\section{PODSUMOWANIE}

Wykorzystanie gazu skroplonego może przynieść UE istotne korzyści. Podstawą do zainteresowania się jego zwiększonym importem będzie rosnący popyt na gaz, konsumowany przez przemysł chemiczny oraz przemysł elektroenergetyczny i ciepłowniczy, motywowany dodatkowo celami ekologicznymi. Biorąc pod uwagę odmienną percepcję bezpieczeństwa energetycznego w poszczególnych państwach członkowskich, wypracowanie i następnie pełne wdrożenie wspólnej polityki unijnej w sektorze LNG będzie trudne. Unia, konsumująca dzisiaj ok. $45 \mathrm{mld} \mathrm{m}^{3} \mathrm{LNG}$ rocznie, co stanowi 13,5\% udziału w światowym rynku gazu skroplonego, ma jednak potencjał do zwiększenia poziomu inwestycji w nowe źródło niskoemisyjnego surowca, jakim jest LNG. Pozytywnie należy ocenić przygotowany przez Komisję Europejską dokument nakreślający strategiczne cele w sektorze.

Budową infrastruktury importowej zainteresowane będą w szczególności państwa Europy Środkowo-Wschodniej oraz Południowej. W przypadku Europy Zachodniej dostawy gazu mają charakter bardziej zdywersyfikowany, a import surowca z Rosji nie jest z tego powodu postrzegany jako czynnik zagrożenia. Państwa te jednak będą motywowane chęcią intensywniejszego korzystania z terminali regazyfikacyjnych w sytuacji napływu gazu skroplonego, m.in. z USA. Niezależnie od tego, czy wzmożony napływ LNG z Ameryki Północnej stanie się faktem, znaczna podaż na rynku LNG sprawi, że część surowca trafi do Europy, o ile będzie istnieć wystarczająca infrastruktura.

Zwiększony import LNG pomoże uczynić europejski rynek gazu bardziej konkurencyjnym. $Z$ uwagi na aktualne uwarunkowania rynkowe prognozowany jest znaczny wzrost transakcji zawieranych w ramach rynku spot, co pozytywnie wpłynie na obniżenie i ujednolicenie cen. Gospodarka zyska na niskim koszcie nabycia surowca, a poszczególne państwa zapewnią sobie bezpieczeństwo dostaw zagwarantowane wielością istniejących kanałów sprowadzania gazu. Już obecnie LNG dla rynków europejskich notowany jest po bardzo niskich cenach, konkurencyjnych nawet wobec tych zawartych w umowach długoterminowych na dostawy gazu za pomocą infrastruktury gazociągowej. Liberalizacja rynku skutkować będzie większym ujednoliceniem cen dla odbiorców europejskich.

Należy skupić się na stworzeniu nowych dróg dostaw gazu skroplonego z państw afrykańskich, Australii oraz innych, poza Katarem, reprezentantów Półwyspu Arabskiego.

232 Tamże, s. 11. 
Konieczne jest wyrażenie aprobaty dla postulatu poprawy dostępu do istniejącej infrastruktury związanej z gazem skroplonym dla wszystkich państw członkowskich w ramach wewnętrznego rynku gazu UE. W tym kontekście na aktualności zyskuje apel Komisji Europejskiej o rezygnację ze wszelkich wyłączeń inwestycji systemowych z obowiązku przestrzegania wymogów trzeciego pakietu energetycznego.

Aby działania poszczególnych państw przebiegały w bardziej skoordynowany sposób, wskazane jest pełne wdrożenie strategii wykorzystania LNG oraz zdolności magazynowych. Wymaga to gotowości państw członkowskich do prowadzenia skoordynowanej polityki, jak również rozbudowy infrastruktury, w tym podziemnych magazynów gazu, która powinna postępować równolegle i komplementarnie do inwestycji w moce regazyfikacyjne LNG. Kluczowe znaczenie mają trzy wytyczne Komisji, dotyczące:

- rozbudowy infrastruktury przesyłowej na linii Północ - Południe oraz Wschód - Zachód (przyłączenie Półwyspu Iberyjskiego do sieci europejskiej);

- budowy nowych terminali regazyfikacyjnych LNG, szczególnie na obszarze Europy Środkowo-Wschodniej, państw bałtyckich oraz Półwyspu Bałkańskiego;

- zagwarantowania pełnej implementacji trzeciego pakietu energetycznego w sektorze gazu (wraz z wydanymi na jego podstawie kodeksami sieci) oraz nowo powstającego rozporządzenia SoS w celu stworzenie przejrzystego, konkurencyjnego i efektywnego rynku energii.

\section{BIBLIOGRAFIA}

\section{Materiały drukowane:}

Gałczyński M. i in., Globalny rynek LNG, red. R. Zajdel, M. Ruszel, Warszawa 2015.

Kaźmierczak T., Bezpieczeństwo energetyczne. Implikacje uzależnienia Polski od importu gazu ziemnego (zarys problemu), Warszawa 2008.

Kiedrowska-Pryka M., Zależności Unii Europejskiej od zewnętrznych dostaw surowców energetycznych - struktura zużycia nośników energii i ich dywersyfikacja w krajach cztonkowskich UE, [w:] Bezpieczeństwo energetyczne. Rynki surowców i energii. Teraźniejszosśc i przysztość, t. 1: Polityka, gospodarka, zasoby naturalne i logistyka, red. P. Kwiatkiewicz, Poznań 2014.

Tański T., Funkcje Terminalu LNG w Świnoujśsiu, [w:] Prawne uwarunkowania konkurencji na rynku gazu, red. B. Popowska, E. Kosiński, P. Lissoń, Warszawa 2015.

\section{Publikacje elektroniczne:}

\section{Literatura źródłowa:}

Aegean LNG - Studies related to permitting procedure, European Commission, I 2016, [online] https://ec.europa.eu/inea/sites/inea/files/fiche_6.9.2-0008-el-s-m-14_final_0.pdf.

BalticConnector will end isolation of Finnish gas market and complete Baltic Gas Ring, European Commission. Energy, 22 XII 2015, [online] https://ec.europa.eu/energy/en/ news/balticconnector-will-end-isolation-finnish-gas-market-and-complete-baltic-gas-ring. 
BP statistical review of world energy, VI 2015, [online] https://www.bp.com/content/dam/ $\mathrm{bp} / \mathrm{pdf} /$ energy-economics/statistical-review-2015/bp-statistical-review-of-world-energy-2015-full-report.pdf.

Canada's Energy Future 2016. Energy supply and demand projections to 2040, Her Majesty the Queen in Right of Canada as represented by the National Energy Board 2016, [online] https://www.neb-one.gc.ca/nrg/ntgrtd/ftr/2016/2016nrgftr-eng.pdf.

Commission Staff working document accompanying the document: Communication from the Commission to the European Parliament, the Council, the European Economic and Social Committee and the Committee of the Regions on an EU strategy for liquefied natural gas and gas storage, European Commission, Brussels, 16 II 2016, [online] http://eur-lex.europa.eu/ legal-content/EN/TXT/PDF/?uri=CELEX:52016SC0023\&from=pl.

Communication from the Commission to the European Parliament, the Council, the European Economic and Social Committee and the Committee of the Regions on an EU strategy for liquefied natural gas and gas storage, European Commission, Brussels, 16 II 2016, [online] https://ec.europa.eu/energy/sites/ener/files/documents/1_EN_ACT_part1_v10-1.pdf.

Consultation on an EU strategy for liquefied natural gas and gas storage, European Commission, 2015, [online] https://ec.europa.eu/energy/sites/ener/files/documents/LNG \%20consultation\%20-\%20publication.pdf.

Current trends \& prospects of natural gas, CEDIGAZ, the International Association for Natural Gas, XII 2015, [online] http://www.cedigaz.org/documents/2015/PresAB2015.pdf.

EU Energy markets in 2014, Luxembourg: Publications Office of the European Union, 2014, [online] http://ec.europa.eu/energy/sites/ener/files/documents/2014_energy_ market_en.pdf.

Komunikat Komisji do Parlamentu Europejskiego i Rady: Europejska strategia bezpieczeństwa energetycznego, Komisja Europejska, Bruksela, 28 V 2014, [online] http://eur-lex.europa. eu/legal-content/PL/TXT/PDF/?uri=CELEX:52014DC0330\&from=PL.

Gas-medium-term marketreport 2015. Market analysis and forecast to 2020, International Energy Agency, 2015, [online] https://www.iea.org/Textbase/npsum/MTGMR2015SUM.pdf.

Impact of US LNG exports on Europe - White Paper, Energy Mining Advisory Partnership, [online] http://energyminingadvisorypartnership.github.io/impact_of_us_lng_on_exports on_europe.pdf.

Key natural gas trends 2015, International Energy Agency, 2015, https://www.iea.org/publications/freepublications/publication/KeyNaturalGasTrends.pdf.

Wniosek - Decyzja Parlamentu Europejskiego i Rady w sprawie ustanowienia mechanizmu wymiany informacji $w$ odniesieniu do umów międzyrządowych $w$ dziedzinie energii między państwami cztonkowskimi a państwami trzecimi i uchylajaca decyzję nr 994/2012/UE, Komisja Europejska, Bruksela, 16 II 2016, [online] https://ec.europa.eu/transparency/regdoc/ rep/1/2016/PL/1-2016-53-PL-F1-1.PDF.

Wniosek - Rozporządzenie Parlamentu Europejskiego i Rady dotyczące środków zapewniajacych bezpieczeństwo dostaw gazu ziemnego i uchylajace rozporzadzenie (UE) nr 994/2010, Komisja Europejska, Bruksela, 16 II 2016, [online] http://eur-lex.europa.eu/legal-content/ $\mathrm{PL} / \mathrm{TXT} / \mathrm{HTML} /$ ?uri=CELEX:52016PC0052\&from=EN. 
Quarterly report on european gas markets. Market observatory for energy, European Commission, DG Energy, vol. 8, issue 3, third quarter of 2015, [online] https://ec.europa. $\mathrm{eu} /$ energy/sites/ener/files/documents/quarterly_report_on_european_gas_markets _q3_2015.pdf.

Quarterly report on european gas markets. Market observatory for energy, European Commission, DG Energy, vol. 7, issue 4, fourth quarter of 2014, [online] https://ec.europa.eu/ energy/sites/ener/files/documents/quarterly_report_on_european_gas_markets_2014 -q4.pdf.

World LNG Report - 2015 edition, International Gas Union, [online] http://www.igu.org/sites/ default/files/node-page-field_file/IGU-World\%20LNG\%20Report-2015\%20Edition.pdf.

2016 World LNG Report, International Gas Union, [online] http://www.igu.org/publications/ 2016-world-lng-report.

- akty normatywne:

Decyzja Parlamentu Europejskiego i Rady nr 994/2012/UE z dnia 25 października 2012 r. $w$ sprawie ustanowienia mechanizmu wymiany informacji w odniesieniu do umów międzyrzadowych w dziedzinie energii między państwami cztonkowskimi a państwami trzecimi, Dz.Urz. UE L 299 z 27 X 2012 r., [online] http://eur-lex.europa.eu/legal-content/PL/TXT/ $\mathrm{PDF} /$ ?uri=CELEX:32012D0994\&from $=\mathrm{PL}$.

Dyrektywa Parlamentu Europejskiego i Rady 2009/73/WE z dnia 13 lipca 2009 r. dotyczaca wspólnych zasad rynku wewnętrznego gazu ziemnego i uchylająca dyrektywe 2003/55/WE, Dz.Urz. UE L 211 z 14 VIII 2009 r., [online] http://eur-lex.europa.eu/legal-content/PL/ TXT/PDF/?uri=CELEX:32009L0073\&from=PL, 29 III 2016

Rozporządzenie Parlamentu Europejskiego i Rady (UE) nr 347/2013 z dnia 17 kwietnia 2013 r. w sprawie wytycznych dotyczacych transeuropejskiej infrastruktury energetycznej uchylajace decyzje nr 1364/2006/WE oraz zmieniajace rozporządzenia (WE) $n r$ 713/2009, (WE) $n r 714 / 2009$ i (WE) $n r$ 715/2009, Dz.Urz. UE L 115 z 5 IV 2013 r., [online] http:// eur-lex.europa.eu/legal-content/PL/TXT/PDF/?uri=CELEX:32013R0347\&from=PL.

Rozporzadzenie Parlamentu Europejskiego i Rady (UE) nr 994/2010 z dnia 20 października 2009 r. w sprawie środków zapewniajacych bezpieczeństwo dostaw gazu ziemnego i uchylenia dyrektywy Rady 2004/67/WE, Dz.Urz. UE L 295 z 12 XI 2010 r., [online] http://eur-lex.europa.eu/legal-content/PL/TXT/PDF/?uri=CELEX:32010R0994 \&from $=$ PL.

Rozporządzenie Parlamentu Europejskiego i Rady (UE) nr 1227/2011 z dnia 25 października 2011 r. $w$ sprawie integralności $i$ przejrzystości hurtowego rynku energii, Dz.Urz. UE L 326 z 8 XII 2011 r., [online] http://eur-lex.europa.eu/legal-content/PL/TXT/ $\mathrm{PDF}$ /?uri=CELEX:32011R1227\&from $=\mathrm{PL}$.

Rozporzadzenie Parlamentu Europejskiego i Rady (WE) nr 715/2009 z dnia 13 lipca 2009 r. $w$ sprawie warunków dostępu do sieci przesytowej gazu ziemnego i uchylajace rozporzadzenie (WE) $n r$ 1775/2005, Dz.Urz. UE L 211 z 14 VIII 2009 r., [online] http://eur-lex.europa. eu/legal-content/PL/TXT/PDF/?uri=CELEX:32009R0715\&from=EN.

Traktat of unkcjonowaniu Unii Europejskiej, Dz.Urz. UE C 326 z 26 X 2012 r.

Ustawa z dnia 10 kwietnia 1997 r. Prawo energetyczne, Dz.U. 1997, nr 54, poz. 348 z późn. zm. 


\section{Literatura pomocnicza:}

\section{- monografie i opracowania:}

Gawlikowska-Fyk A., Gruszczyński W., Nowak Z., Pakiet gazowy: kolejny etap starań o wzmocnienie odporności energetycznej UE, Biuletyn Polskiego Instytutu Spraw Międzynarodowych, nr 9 (1359), 3 II 2016, [online] https://www.pism.pl/files/?id_plik=21337.

Sikora A., Sikora M., LNG wyrusza na poszukiwanie nowych rynków, Centrum Informacji o Rynku Energii, [online] http://www.cire.pl/pokaz-pdf-\%252Fpliki\%252F2\%252Fl ng_19012016.pdf.

Zajdler R., Komentarz do dyrektywy Parlamentu Europejskiego i Rady 2009/72/WEz dnia 13 lipca 2009 r. dotyczącej wspólnych zasad rynku wewnętrznego energii elektrycznej i uchylającej dyrektywe 2003/54/WE (Dz.U.UE.L.09.211.55), LEX/el., 2011, [online] http://lex.adm. uj.edu.pl/lex/index.rpc?\&fromHistory=false\#content.rpc $-A S K-$ nro $=201335083 \&$ wersja $=0$ \&localNroPart $=587300583 \&$ fullTextQuery.query $=2003 \% 252 \mathrm{~F} 55 \&$ reqI $\mathrm{d}=1461400800806 \_1046599685 \&$ class $=$ CONTENT $\&$ loc $=4 \&$ full $=1 \& \mathrm{hId}=2$.

Zajdler R., Polski rynek hurtowy gazu ziemnego na tle rynków Unii Europejskiej, Warszawa 2014, [online] http://www.zajdler.eu/raporty/show_pdf.php?ID=8.

- artykuły w czasopismach naukowych:

Baily J., Lidgate R., LNG price reviews: a sign of the times, „Journal of World Energy Law and Business" 2014, vol. 7, no. 2, [online] DOI: 10.1093/jwelb/jwt017.

Bohmer L., Arbitrating international LNG disputes: lessons learned over two decades, „Journal od World Energy Law and Business” 2015, vol. 8, no. 5, [online] DOI: 10.1093/jwelb/jwv025. Brito D. L., Hartley P. R., Expectations and the evolving world gas market, „The Energy Journal” 2007, vol.28, no. 1, [online] https://extranet.uj.edu.pl/ehost/pdfviewer/,DanaInfo=web.a.ebscohost.com + pdfviewer ?vid=9\&sid=aaf7578f-0ab2-480a-9159-b8be3eaca4f6\%40sessi onmgr4001\&hid $=4204$.

De Micco P., Could US oil and gas exports be a game changer for EU energy security?, European Parliament, Directorate-General for Energy Policies, II 2016, [online] http://www.europarl. europa.eu/RegData/etudes/IDAN/2016/570462/EXPO_IDA(2016)570462_EN.pdf.

Deutch J., The good news about gas: the natural gas revolution and its consequences, „Foreign Affairs" 2011, vol. 90, no. 1, [online] https://www.foreignaffairs.com/articles/2011-01-01/ good-news-about-gas.

Grobarčíková A., Sosedová J., Kalina T., Development of LNG Infrastructure in Europe, „Naše more" 2016, vol. 63, no. 1, [online] DOI: 10.17818/NM/2016/1.5.

Liuhto K., A liquefied natural gasterminal boom in the Baltic Sea region?, „Electronic Publications of the Pan-European Institute" 2012, vol. 5, [online] https://www.utu.fi/fi/yksikot/tse/yksikot/PEI/raportit-ja-tietopaketit/Documents/Liuhto\%20LNG.pdf.

Neumann A., Linking Natural Gas Markets - Is LNG Doing its Job?, „The Energy Journal” 2009, vol. 30, special issue: World Natural Gas Market and Trade: A Multi-Modelling Perspective.

Ruszel M., Znaczenie terminali LNG na wspólnym rynku gazu ziemnego, „Polityka i Społeczeństwo" 2014, nr 4.

Sikora A., Lenartowicz P., Sen o gazie. $L N G$ a polska energetyka, „Energetyka Cieplna i Zawodowa" 2015, nr 7, [online] http://www.ise.com.pl/wp-content/uploads/2015/11/ Sen-o-gazie_ECiZ-7_2015.pdf. 


\section{- artykuły internetowe:}

Budowa polsko-duńskiego gazociagu „Baltic Pipe” już za cztery lata, Polskie Radio, 21 III 2015, [online] http://www.polskieradio.pl/5/3/Artykul/1597623,Budowa-polsko-dunskiegogazociagu-Baltic-Pipe-juz-za-cztery-lata.

Carroll J., Malik N., Shale hoard behind U.S. energy renaissance set loose on globe, Bloomberg, 4 I 2016, [online] http://www.bloomberg.com/news/articles/2016-01-04/ shale-hoard-behind-u-s-energy-renaissance-set-loose-on-globe.

Crooks E., Cheniere's Energy shipment turns US into gas exporter, „Financial Times” 2016, 10 I, [online] http://www.ft.com/intl/cms/s/0/f1773832-b5ee-11e5-b147-e5e5bba42e51. html\#axzz46doQACm2

Dudek J., Czy uda się uratować Unię energetyczną?, Centrum Analiz Klubu Jagiellońskiego, 21 II 2016, [online] http://cakj.pl/2016/02/21/czy-uda-sie-uratowac-unie-energetyczna/.

First Poland LNG station opened, LNG World News, 5 I 2016, [online] http://www.lngworldnews.com/first-polish-lng-station-opened/.

Furman T., Al Nuaman zacumowat w Świnoujściu, „Parkiet” 2015, 11 XII, [online] http:// www.parkiet.com/artykul/1452950.html.

Jakóbik W., Litwa chciataby wczénniejszego wykupu FSRU z dzierżawy, Centrum Informacji o Rynku Energii, 14 VIII 2015, [online] http://www.cire.pl/item,115658,1,0,0,0,0,0,litwa-chcialaby-wczesniejszego-wykupu-fsru-z-dzierzawy.html.

Jegelevicius L., Estonia's LNG plans hit reality check, Natural Gas Europe, 8 II 2016, [online] http://www.naturalgaseurope.com/estonia-tallinn-lng-terminal-prospects-dampenedrevised-lithuania-statoil-contract-28030.

Kempny M., Podsumowanie, LNG Snapshot, 21 X 2015, [online] http://lngsnapshot. $\mathrm{com} / \mathrm{?} \mathrm{p}=347$.

Krzyczkowski W., Dzięki atomowi Japonia potrzebuje mniej LNG, Wysokie Napięcie, 28 XII 2015, [online] http://wysokienapiecie.pl/gaz-ziemny/1184-dzieki-atomowi-japoniapotrzebuje-mniej-lng.

Krzyczkowski W., LNG w 2016: nowa podaz, dodatkowi odbiorcy, Wysokie Napięcie, 25 I 2016, [online] http://wysokienapiecie.pl/gaz-ziemny/1244-lng-w-2016-dodatkowapodaz-nowi-odbiorcy.

Kublik A., Gazprom Germania zarobi w Warszawie na gazowych autobusach, Wyborcza. biz, 7 XI 2013, [online] http://wyborcza.biz/biznes/1,147744,14914096,Gazprom_ Germania_zarobi_w_Warszawie_na_gazowych_autobusach.html.

LNG wyraźnie zyskuje na znaczeniu, Portal Gospodarczy Nowy Przemysł, 21 VIII 2015, [online] http://gazownictwo.wnp.pl/lng-wyraznie-zyskuje-na-znaczeniu,255911_1_0_0.html.

Loh T., Buurma C., Weber H., American LNG exporters turn to Europe as Asian demand sputters, Bloomberg, 22XII 2015, [online] http://www.bloomberg.com/news/articles/2015-12-22/ american-lng-exporters-turn-to-europe-as-asian-demand-sputters.

Loskot-Strachota A., The case against Nord Stream II, Energy Post, 23 XI 2015, [online] http:// www.energypost.eu/case-nord-stream-2/.

Malinowski D., Gazprom kupi LNG w Kamerunie, Portal Gospodarczy Nowy Przemysł, 30 XI 2015, [online] http://gazownictwo.wnp.pl/gazprom-kupi-lng-w-kamerunie, 262400_1_0_0.html. 
Malinowski D., LNG dla Polski może znacznie potanieć?, Portal Gospodarczy Nowy Przemysł, 19 I 2016, [online] http://gazownictwo.wnp.pl/lng-dla-polski-moze-znacznie-potaniec,265553_1_0_0.html.

Owoce tupkowej rewolucji ptyna do Europy, Biznes Alert, 14 I 2016, [online] http://biznesalert. $\mathrm{pl}$ /owoce-lupkowej-rewolucji-plyna-do-europy/.

Rekord importu LNG pobity... Dzięki Europie, LNG Snapshot, 13 IV 2016 [online] http://lngsnapshot.com/?p=448.

Rühl C., Global energy after the crisis. Prospects and priorities, „Foreign Affairs”2010, vol. 89, no. 2, [online] https://www.foreignaffairs.com/articles/2010-03-01/global-energy-after-crisis.

Ruszel M., Polityczne znaczenie terminalu LNG, Energetyka24/Defence24, 8 IV 2014, [online] http://energetyka.defence24.pl/73930,polityczne-znaczenie-terminali-lng.

Sergie M., Biggest no longer means best in Qatar's strategy for $L N G$ wealth, Bloomberg, 6 I 2016, [online] http://www.bloomberg.com/news/articles/2016-01-06/biggestno-longer-means-best-in-qatar-s-strategy-for-lng-wealth.

Shiryaevskaya A., More than half of U.S. LNG is destined for Europe, WoodMac says, Bloomberg Business, 15 I 2016, [online] http://www.bloomberg.com/news/articles/2016-01-15/ more-than-half-of-u-s-lng-is-destined-for-europe-woodmac-says.

Szczęśniak A., Światowy rynek LNG, blog autora Szczesniak.pl, 11 VI 2014, [online] http:// szczesniak.pl/2676.

Terminale importowe LNG sq inwestycjami strategicznymi, LNG Snapshot, 23 IX 2015, [online] http://lngsnapshot.com/?p=181.

Unia Europejska - LNG może skorzystać na wzrostowym trendzie konsumpcji gazu, LNG Snapshot, 22 XI 2015, [online] http://Ingsnapshot.com/?p=326.

Vella M., Gas pipeline retains EU status for future funding, „Malta Today” 2015, 18 XI, [online] http://www.maltatoday.com.mt/news/national/59395/gas_pipeline_retains_eu_status_ for_future_funding.

Yergin D., Stoppard M., The next prize, „Foreign Affairs” 2003, vol. 82, no. 6, [online] https:// www.foreignaffairs.com/articles/2003-11-01/next-prize.

Zajdler R., LNG tańsze o potowę, LNG Snapshot, 25 XI 2015, [online] http://lngsnapshot. $\mathrm{com} / \mathrm{p}=336$.

Zajdler R., W marcu 2016 r. ropa drożata, a gaz taniat, LNG Snapshot, 13 IV 2016, [online] http://lngsnapshot.com/?p=437.

Zajdler R., Zajdler: Rozporządzenie SoS czyli jak uszczelnić bezpieczeństwo gazowe UE, Biznes Alert, 12 II 2015, [online] http://biznesalert.pl/zajdler-rozporzadzenie-sos-czyli-jak-uszczelnic-bezpieczenstwo-gazowe-unii-energetycznej/.

Znaczne korekty dtugoterminowej prognozy, LNG Snapshot, 21 X 2015, [online] http://lngsnapshot.com/?p=351.

Zubkov: Gazprom in 2016 could supply Europe with 160 billion cubic meters of gas, FreeNews, 20 I 2016, [online] http://freenews.xyz/2016/01/20/zubkov-gazprom-in-2016-couldsupply-europe-with-160-billion-cubic-meters-of-gas-2/. 


\section{Strony internetowe:}

Centrum Informacji o Rynku Energii, [online] http://www.cire.pl.

European Environment Agency, [online] http://www.eea.europa.eu.

Eurostat, [online] http://ec.europa.eu/eurostat.

Gas in Focus, [online] http://www.gasinfocus.com/en.

Gas Infrastructure Europe, [online] http://transparency.gie.eu.

Gastrade S.A. - strona oficjalna, [online] http://www.gastrade.gr/en.

Latvijas Gaze, [online] http://www.lg.lv/index.php?switch=1\&lang=eng.

LNG Croatia LLC, [online] http://www.lng.hr/en.

LNG - Terminal Gothenburg - strona oficjalna, [online] http://www.lngterminalgothenburg. $\mathrm{com} /$.

Strona internetowa Ministerstwa Energii, [online] http://www.mg.gov.pl.

Strona internetowa Ministerstwa Skarbu Państwa, [online] http://www.msp.gov.pl.

Portal „Polskie LNG”, http://www.polskielng.pl.

Portal Urzędu Regulacji Energetyki, [online] http://www.ure.gov.pl.

Mateusz BĄK - student V roku studiów na kierunku prawo na Uniwersytecie Jagiellońskim. Absolwent studiów I stopnia na kierunku bezpieczeństwo narodowe na UJ. Interesuje się problematyką sektora energetycznego. 